\title{
Upper Devonian microvertebrates from the Canning Basin, Western Australia
}

\author{
BRETT ROELOFS $^{1}$, TED PLAYTON² ${ }^{2}$ MILO BARHAM ${ }^{3}$ AND KATE TRINAJSTIC ${ }^{4}$ \\ ${ }^{1}$ Department of Applied Geology, Curtin University, GPO Box U1987 Perth, Western Australia 6845, Australia. \\ E-mail:brett.roelofs@curtin.edu.au \\ ${ }^{2}$ Chevron Energy Technology Company, Houston, Texas, USA*.E-mail: tedplay@tengizchevroil.com \\ ${ }^{3}$ Department of Applied Geology, Curtin University, GPO Box U1987 Perth, Western Australia 6845, Australia. \\ E-mail:milo.barham@curtin.edu.au \\ ${ }^{4}$ Department of Environment and Agriculture, Curtin University, GPO Box U1987, Perth, \\ Western Australia 6845, Australia.E-mail: K.Trinajstic@curtin.edu.au. \\ *Tengizchevroil, Atyrau, Kazakhstan (current address)
}

\begin{abstract}
:
Roelofs, B., Playton, T., Barham, M. and Trinajstic, K. 2015. Upper Devonian microvertebrates from the Canning Basin, Western Australia. Acta Geologica Polonica, 65 (1), 69-100. Warszawa.

A diverse microvertebrate fauna is described from the Virgin Hills and Napier formations, Bugle Gap Limestone Canning Basin, Western Australia. Measured sections at Horse Spring and Casey Falls (Virgin Hills Formation) and South Oscar Range (Napier Formation) comprise proximal to distal slope carbonates ranging in age from the Late Devonian Frasnian to middle Famennian. A total of 18 chondrichthyan taxa are identified based on teeth, including the first record of Thrinacodus tranquillus, Cladoides wildungensis, Protacrodus serra and Lissodus lusavorichi from the Canning Basin. A new species, Diademodus dominicus sp. nov. is also described and provides the first record of this genus outside of Laurussia. In addition, the upper range of Australolepis seddoni has been extended to Late Devonian conodont Zone 11, making it the youngest known occurrence for this species. The Virgin Hills and Napier formations microvertebrate faunas show close affinities to faunas recovered from other areas of Gondwana, including eastern Australia, Iran, Morocco and South China, which is consistent with known conodont and trilobite faunas of the same age.
\end{abstract}

Key words: Vertebrate palaeontology; Chondrichthyes; Thelodonti; Frasnian; Famennian; Lennard Shelf; Gondwana.

\section{INTRODUCTION}

The Canning Basin, Western Australia (Text-fig. 1) is well known for the preservation of Devonian reef complexes as well as both invertebrate and vertebrate fossils (Playford et al. 2009; Klapper 2007; Becker et al. 1993), many of which have proved important in studies of biostratigraphy and correlation. Conodont and ammonoid faunas have both been extensively used in biostratigraphy over the past century with conodont zonations established for the Frasnian (Glenister and Klapper 1966; Klapper 2007; Nicoll and Playford 1993; Metzger 1994) as well as ammonoid zonations for the Frasnian and Famennian (Peterson 1975; Becker et al. 1993; Becker 2000) recognised in the Canning Basin. These fossils have proven useful in determining ages of slope and basin strata enabling successful correlation across physically disconnected localities (Glenister and Klapper 1966; Becker et al. 1993; Becker 2000). However, correlation between slope and platform facies 
within the Canning Basin remains problematic as many conodont and ammonoid faunas are absent or undiagnostic in shallow water environments. In contrast, microvertebrates have proven useful in correlating such environments (Turner 1997; Hairapetian et al. 2000; Trinajstic and George 2009). To date, globally correlative microvertebrate zonations are best resolved for the Silurian and early to middle Devonian (Turner 1993; Young 1995; Burrow and Simpson 1995; Valiukevicius 1995; Burrow 1996, 1997; Turner 1997; Burrow and Turner 1998, 2000; Basden et al. 2000; Valiukevicius and Kruchek 2000). Furthermore, a Late Devonian zonation scheme based on phoebodont sharks has been established from the Frasnian to the end Famennian (Ginter and Ivanov 1995a; Ginter 2000; Jones and
Turner 2000; Young and Turner 2000). Where known, the Devonian shark fauna of Western Australia (Trinajstic and George 2009; Trinajstic et al. 2014) has been correlated to the Frasnian phoebodont zonation of Ginter and Ivanov (1995a). However, to date little work has been published on Famennian shark taxa from Western Australia. Thelodont zonation has also recently been extended into the Famennian (Hairapetian et al., in press), although the known taxa are currently restricted to Iran and north-western Australia because other thelodonts appear to have become extinct at the end of the Givetian in other areas of the world (Turner 1997; Trinajstic 2001; Märss et al. 2007).

Detailed taxonomic studies on vertebrate faunas of Frasnian-age strata have been undertaken in the

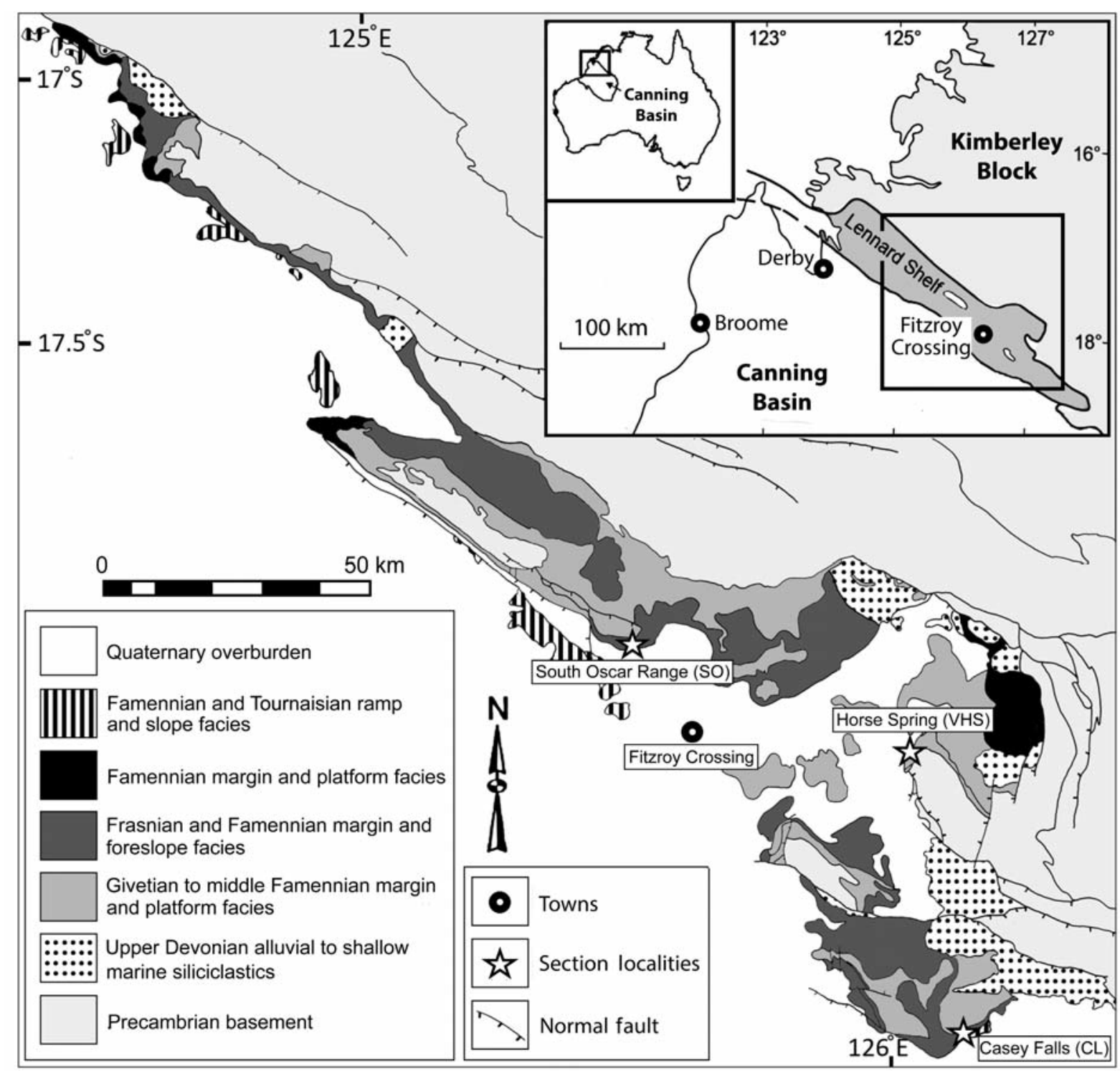

Text-fig. 1. Simplified geological map of the Devonian Reef complexes of the Lennard Shelf, northern Canning Basin, showing the South Oscar Range, Horse Spring and Casey Falls measured sections and main facies types (modified after Playford et al. 2009) 
Carnarvon (Turner and Dring 1981; Long 1991; Trinajstic and George 2009) and Canning basins of Western Australia (Long and Trinajstic 2000; Trinajstic and George 2009; Long and Trinajstic 2010) with greatest number of studies in Western Australia done on the Frasnian macrovertebrate faunas of the Gogo Formation (see Trinajstic et al. 2014 for a review). Biostratigraphic studies into vertebrate faunas, from both the Canning and Carnarvon basins however, are less common.

The utility of Western Australian microvertebrates to date strata has been, in part, due to the ability to identify isolated scales through comparison with the exceptionally preserved fauna from the Frasnian Gogo Formation. This has been most successful with placoderms (Trinajstic 1999a), acanthodians (Burrow et al. 2010) and palaeoniscoids (Trinajstic 1999b). However, a single articulated shark (Long and Trinajstic 2010), which is not comparable with any of the isolated teeth recovered so far, has been reported from the Gogo Formation. A second, incomplete specimen comprising meckels cartilage, a shoulder girdle and associated teeth has highlighted the high degree of heterodonty present in Frasnian sharks and the recognition of this variation is important when diagnosing species from isolated teeth. Previous microvertebrate studies in the Canning and Carnarvon basins have revealed the presence of the youngest-recorded thelodont scales, first in early Frasnian strata of the Carnarvon Basin (Turner and Dring 1981) and later, younger scales in the middle Frasnian (Trinajstic and George 2009) and middle Famennian of the Canning Basin (Hairapetian et al., in press).

In contrast to Frasnian vertebrate faunas, Famennian macrovertebrates from Western Australia are rare (Trinajstic et al. 2014), with bothriolepid and phyllolepid placoderms reported from the Willaraddie Sandstone in the Carnarvon Basin (Long and Trinajstic 2000) and coccosteid and dinichthyid placoderms described from the Napier and Virgin Hills formations in the Canning Basin (Long 1987; Trinajstic et al. 2014). Microvertebrate taxa from the Famennian in Canning Basin are even more understudied than those of the Frasnian with only a few reports of dipnoan, acanthodian and chondrichthyan remains from the Gumhole Formation and lower parts of the Yellow Drum Formation (Young 1987; Turner 1993; Edwards 1997; Burrow et al. 2010; Trinajstic et al. 2014). Although rare, thelodont scales as well as the teeth of Stethacanthus cf. thomasi and Thrinacodus ferox

\begin{tabular}{|c|c|c|c|c|c|c|c|c|c|c|c|c|c|}
\hline \multirow[t]{2}{*}{ Localities } & \multicolumn{7}{|c|}{$\begin{array}{l}\text { Casey Falls } \\
\text { (CL) }\end{array}$} & \multirow{2}{*}{ 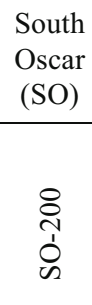 } & \multicolumn{5}{|c|}{$\begin{array}{l}\text { Horse Spring } \\
\text { (VHS) }\end{array}$} \\
\hline & $\stackrel{a}{\dot{c}}$ & $\frac{n}{\stackrel{N}{J}}$ & 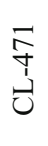 & 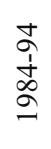 & $\begin{array}{l}\circ \\
\text { ì } \\
\infty \\
\infty\end{array}$ & $\begin{array}{l}\hat{a} \\
\dot{j} \\
\infty \\
\stackrel{a}{a}\end{array}$ & $\begin{array}{l}\stackrel{\infty}{\stackrel{1}{+}} \\
\stackrel{\infty}{=}\end{array}$ & & $\begin{array}{l}\infty \\
0 \\
\infty \\
1 \\
\infty \\
1 \\
>\end{array}$ & $\begin{array}{l}\stackrel{0}{m} \\
\dot{n} \\
\dot{p} \\
\dot{p}\end{array}$ & $\begin{array}{l}= \\
\dot{n} \\
\dot{n} \\
\dot{3}\end{array}$ & 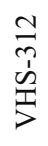 & $\begin{array}{l}\frac{n}{m} \\
\dot{n} \\
\frac{1}{5}\end{array}$ \\
\hline Australolepis seddoni & & & & & & & & & & & & & 1 \\
\hline Phoebodus bifurcatus & & & & & & & & & 2 & 1 & & 1 & 2 \\
\hline Phoebodus fastigatus & & & & & & & & & & 1 & 4 & 8 & 1 \\
\hline Phoebodus cf. fastigatus & & & & & & & & & & & 1 & 2 & \\
\hline Phoebodus latus & & & & & & & & & & 4 & 3 & 1 & \\
\hline Phoebodus sp. 1 & & & & & & & & & & & & 1 & \\
\hline Diademodus dominicus sp. nov. & & & & & & & & & & 2 & & & \\
\hline Thrinacodus tranquillus & & 1 & 3 & & & 7 & 2 & & & & & & \\
\hline Stethacanthus sp. 1 & & & 1 & & & & 1 & & & & & & \\
\hline Cladoides cf. wildungensis & 1 & & & & & & & & & & & & 1 \\
\hline Ctenacanthiform gen. et sp. indet 1 & & & & & & & & 1 & & & & & \\
\hline Ctenacanthiform gen. et sp. indet 2 & & & & & & 1 & & 1 & & & & & \\
\hline Protacrodus serra & & & & 1 & & 1 & & & & & & & \\
\hline Deihim mansureae & & & 1 & & 1 & 2 & 4 & & & & & & \\
\hline Deihim cf. mansureae & & & & & & & 2 & & & & & & \\
\hline Deihim sp. 1 & & & 1 & & & & & & & & & & \\
\hline Protacrodontidae gen. et sp. indet. 1 & & & & 1 & & & & & & & & & \\
\hline ?Protacrodontidae fam. gen. sp. indet. & & & & & & & 1 & & & & & & \\
\hline Lissodus lusavorichi & & & & & & & 2 & & & & & & \\
\hline Total & 1 & 1 & 6 & 2 & 1 & 11 & 12 & 2 & 2 & 8 & 8 & 13 & 5 \\
\hline
\end{tabular}

Table 1. Distribution and abundances of microvertebrate remains from sections measured at Horse Spring, South Oscar and Casey Falls, Canning Basin, Western Australia 
Turner, 1982, and a possible Late Famennian otolith have been reported from the Middle to Late Famennian in the Napier Formation (Turner 1993; Trinajstic et al. 2014; Hairapetian et al., in press). Even with a small number of Famennian microvertebrate fossils, the presence of Thrinacodus ferox and Famennian thelodonts, indicates a faunal connection with other areas in north Gondwana.

This work readdresses a previous lack of study through the description of a microvertebrate fauna recovered from measured sections (Text-fig. 2; Table 1) that encompass distal slope to platform top facies and crop out along the Lennard Shelf in the Canning Basin of Western Australia. The discontinuous nature of the reef complexes has meant the use of microvertebrates adds a significant control to how the Lennard Shelf carbonate system is correlated and reconstructed. Microvertebrates recovered from sampled strata are compared with the known age ranges reported from other sites globally as well as those species previously described from north-western Australia. In addition to providing the first comprehensive study into Late Famennian chondrichthyans within the Canning Basin, this work also determines faunal links between the Canning Basin and other areas along the margins of northern Gondwana and southern Laurussia.

\section{MATERIALS AND METHODS}

Carbonate rock samples $(\sim 20 \mathrm{~kg}$ each) were processed in a $10 \%$ buffered acetic acid solution at Macquarie and Curtin universities (following the methodology of Jeppsson et al. 1999), with resulting residues further separated by either heavy liquid fractionation (Macquarie University) or sieving ( 0.125 mm sieve; Curtin University) before being picked under a Nikon stereomicroscope. Both conodont and microvertebrate remains were well preserved with the conodont elements indicating a Conodont Alteration Index (CAI) of 1. For SEM photography, specimens were mounted on adhesive carbon tape fixed to $10 \mathrm{~mm}$ diameter aluminium stubs and coated with $5 \mu \mathrm{m}$ of platinum. Specimens were imaged using a Zeiss Evo 40XVP SEM at the Centre for Materials Research at Curtin University as well as a Hitachi TM-3030 desktop SEM at Applied Geology at Curtin University with accelerating voltages ranging from $5-15 \mathrm{kV}$ and under variable pressure.

The 13-fold Montagne Noire (MN) conodont Zonation (Klapper 1989, 2007) modified by Girard et al. (2005) was used to determine the age ranges of the associated Frasnian microvertebrates recovered in this study, as it provides greater resolution than that of Zeigler and Sandberg (1990). The standard conodont Zonation (Zeigler and Sandberg 1990) is used in the Famennian.

Microvertebrate specimens are housed at the Western Australian Museum (WAM).

\section{GEOLOGICAL SETTING}

Throughout the Devonian, the Canning Basin (Textfig. 1) occupied an equatorial position, approximately $12-14^{\circ}$ south of the equator, along the northern margins of Gondwana (Scotese and McKerrow 1990). Development of the basin was initiated during the Ordovician. Following a period of uplift and erosion in the early Devonian, extension during the middle Devonian to early Carboniferous led to rapid subsidence of the NW trending Fitzroy Trough along the northern margin of the Canning Basin (Drummond et al. 1991). The margin successions include the late Givetian to late Famennian reef complexes, which are well exposed along the inner Lennard Shelf, and include numerous wellpreserved fossilised fringing reefs and atolls (Playford 1980). Difficulty in correlating Frasnian and Famennian sections within the Lennard Shelf is partly due to a complex underlying topography on which the reef was established, as well as depositional heterogeneity (Playford et al. 2009). Tectonic activity during the period of reef building (Chow et al. 2013) and deformation following post-depositional exhumation have also added to a fragmentary Frasnian and Famennian record across the basin (Playford et al. 2009).

\section{Studied sections}

\section{Casey Falls}

A section was measured at Casey Falls $\left(18^{\circ} 44^{\prime} 0^{\prime \prime} \mathrm{S}\right.$, $126^{\circ} 05^{\prime} 8^{\prime \prime} \mathrm{E}$; Text-figs 1 and 2) approximately $80 \mathrm{~km}$ south east of Fitzroy Crossing (Text-fig. 1). The measured section represents $420 \mathrm{~m}$ of toe-of-slope to upper slope carbonate sediments of the Virgin Hills Formation and overlying Bugle Gap Limestone, respectively (Table 2). The lower $100 \mathrm{~m}$ of the section mainly comprises resedimented silty skeletal to non-skeletal wackestone/packstones derived from platform, margin and slope environments. The upper $320 \mathrm{~m}$ consists mostly of stromatactoid microbial boundstones and microbially stabilised packstones and grainstones (Playton et al. 2013). Minor platform derived skeletal-peloidal pack- 
UPPER DEVONIAN MICROVERTEBRATES FROM WESTERN AUSTRALIA

stones and grainstones occur in the upper $40 \mathrm{~m}$ of the section. The Frasnian strata within the section are limited to the first $2 \mathrm{~m}$ of the section and range from Conodont zones (CZ) 13a to $13 \mathrm{~b}$, with zone $13 \mathrm{c}$ not resolvable. The Frasnian-Famennian boundary is located between 2.2 and $7.9 \mathrm{~m}$ above the section base, however finer biostratigraphic resolution was impossible at this level due to a paucity of conodonts. Overlying Famennian sediments, from $7.9 \mathrm{~m}$, yield conodont zones from Late triangularis to Late marginifera $\mathrm{CZ}$. Addi-

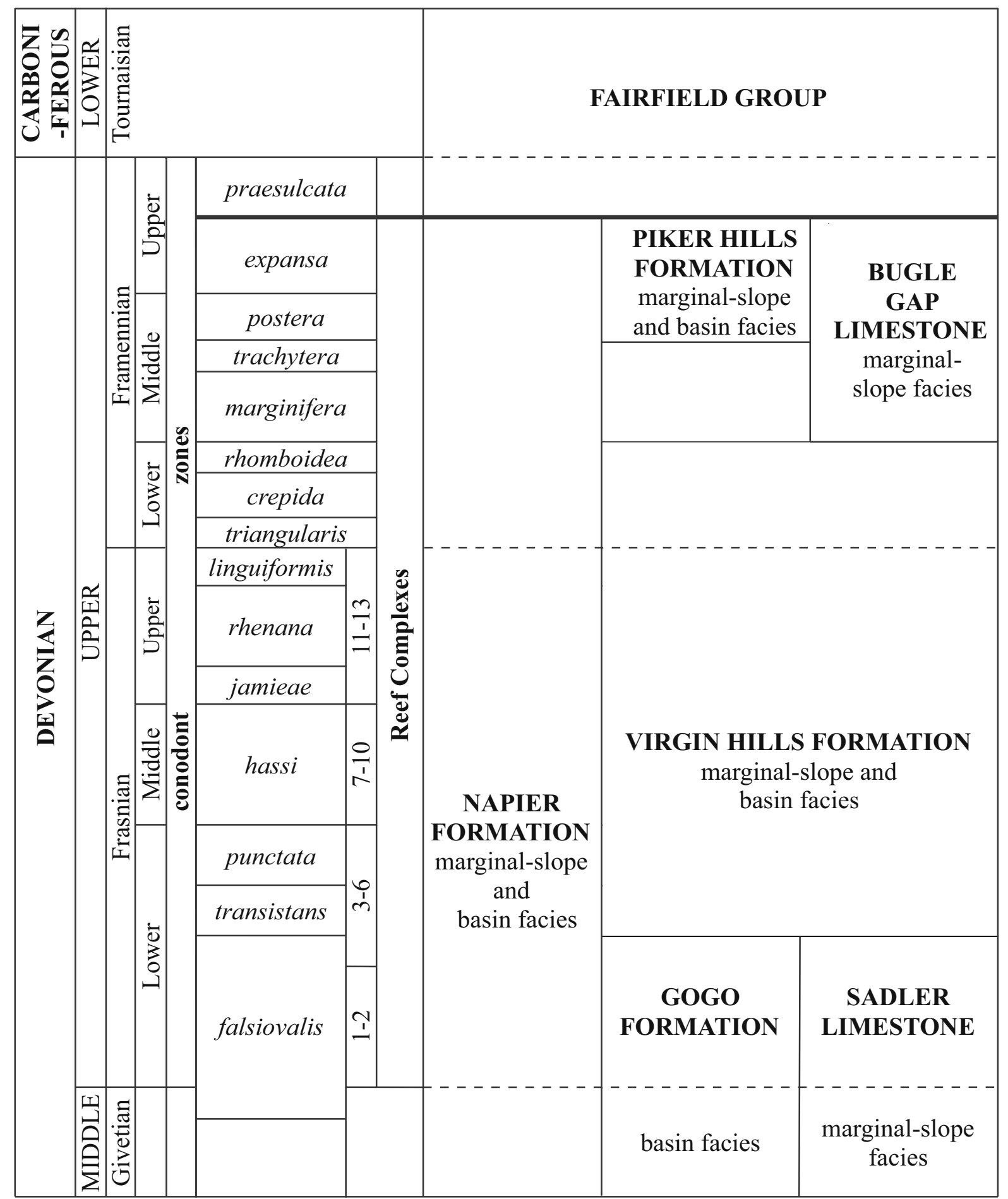

Table 2. Correlation table of Upper Devonian and Lower Carboniferous units on the Lennard Shelf (after Playford et al. 2009). The discontinuous nature of the reef complexes coupled with the large geographic range of the outcrops resulted in contemporaneous facies receiving different formation names. Dashed lines represent chronostratigraphic boundaries; bold line represents the cessation of reef building in the Canning Basin 
tional samples were taken from poorly outcropping beds approximately $580 \mathrm{~m}$ north (samples 1984-95 and 1984-96) and $600 \mathrm{~m}$ (samples 1984-97 and 1984-98) north-north-east from the top of the measured section at
Casey Falls with conodonts indicating a Late marginifera age. These samples represent the shallow water carbonate derived material of the Bugle Gap Limestone.

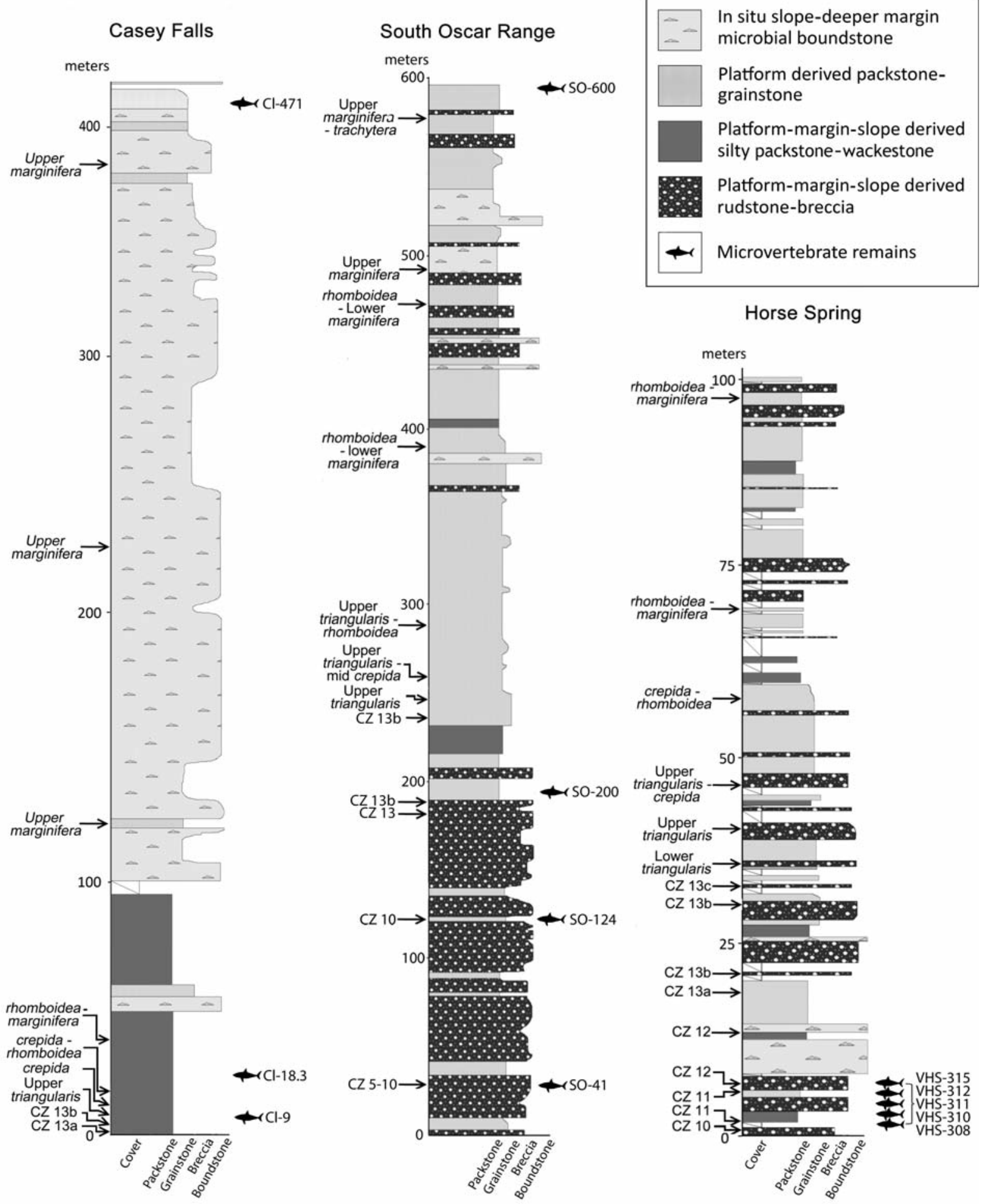

Text-fig. 2. Simplified stratigraphic columns of the sections at Horse Spring, Casey Falls and South Oscar Range, showing main facies types and locations of recovered microvertebrate remains (modified after Playton et al. 2013) 


\section{South Oscar Range}

The section measured at the southern end of South Oscar Range (17 $54^{\prime} 53^{\prime \prime} \mathrm{S}, 125^{\circ} 17^{\prime} 56^{\prime \prime} \mathrm{E}$, Text-figs 1 and 2) spans $585 \mathrm{~m}$ of the Napier Formation and represents the seaward side of an offshore island and fringing reef complex (Playford et al. 2009). The preserved sequence comprises transported slope facies dominated by platform derived packstones and grainstones/rudstones with commonly occurring peloids, coated grains and skeletal fragments. Debris deposits consisting of allochthonous blocks and megabreccias of reefal margin material can occur locally and are concentrated in particular parts of the section, reflecting brittle failure of the early-lithified bound margin. Bioclasts are abundant throughout the entire section and dominated by branching and laminar stromatoporoids (in the Frasnian; George 1999; Stephens and Sumner 2003), crinoids, corals and brachiopods. The Frasnian beds range from MN 6 to $13 \mathrm{~b}$ CZ and in addition to conodonts, yielded chondrichthyan teeth and scales as well as acanthodian scales. The Frasnian-Famennian boundary was located between 228.7 and 233 $\mathrm{m}$ above the section base. The Famennian portion of the section ranges from Upper triangularis to marginfera $\mathrm{CZ}$ with only the uppermost bed containing microvertebrate remains including acanthodian and palaeoniscoid scales as well as the youngest thelodont scales currently known (Hairapetian et al., in press).

\section{Horse Spring}

The section measured at Horse Spring (GSWA reference section WCB 364) is located approximately 42 $\mathrm{km}$ east of Fitzroy Crossing, at the northern extremity of the Hull and Horse Spring Ranges (18 $41^{\prime} 11^{\prime \prime} \mathrm{S}$, $126^{\circ} 05^{\prime} 12^{\prime \prime}$; Text-figs 1 and 2). The section represents a lower slope succession dominated by platform derived skeletal to non-skeletal packstones and grainstones, slope derived rudstones, and margin-derived megabreccias. Stromatolitic and stromatactoid boundstones are minor and found in Frasnian beds, representing periods of deep-water in situ encrustation. The section at Horse Spring has been previously dated using conodonts (Klapper 1989; 2007) and goniatites (Becker et al. 1993), with the Frasnian-Famennian boundary located between 34.6 and $36.6 \mathrm{~m}$ above the section base. A diverse Frasnian microvertebrate fauna has also been recorded by Trinajstic and George (2009) with scales of the thelodont Australolepis seddoni Turner and Dring, 1981 recorded as occurring with conodont elements and phoebodont teeth for the first time, thus allowing the age of $A$. seddoni to be constrained to MN 4-10 CZ. The phoebodont teeth were also correlated to the known phoebodont based zonation of Ginter and Ivanov (1995a).

\section{SYSTEMATIC PALAEONTOLOGY}

Class Thelodonti Jaekel, 1911

Order Thelodontiformes Kiaer, 1932

Family Turiniidae Obruchev, 1964

Genus Australolepis Turner and Dring, 1981

TYPE SPECIES: Australolepis seddoni Turner and Dring, 1981

Australolepis seddoni (Turner and Dring, 1981)

(Text-fig. 3A)

1969. Fish tooth type b; Seddon, p 30, fig. 2a-b.

1981. Australolepis seddoni sp. nov.; Turner and Dring, 43, figs 3A-P, 4A-K.

1981. Nikoliviid gen. et sp. indet. Turner and Dring: 46, fig. $6 \mathrm{~A}-\mathrm{C}$.

1993. Australolepis seddoni Turner and Dring, 1981; Turner, p. 183 , fig. 8.3 .

1997. Australolepis seddoni Turner and Dring, 1981; Turner, p. 309 , fig. 8 .

2000. Australolepis seddoni Turner and Dring, 1981; Long and Trinajstic, p. 472, fig. 1.

2000. Australolepis seddoni Turner and Dring, 1981; Yazdi and Turner, p. 225, fig. 2.1.

2001. Australolepis seddoni Turner and Dring, 1981; Trinajstic, p. 239, fig. 2A-L, fig. 4.

2002. Australolepis seddoni Turner and Dring, 1981; Turner et al., p. 151, fig. 8.

2009. Australolepis seddoni Turner and Dring, 1981; Trinajstic and George, p. 647-648, pl. 1, figs 1-8.

2013. Australolepis seddoni Turner and Dring, 1981; Chow et al., pl. 1C.

2014. Australolepis seddoni Turner and Dring, 1981; Hairapetian et al., in press.

MATERIAL: One broken scale from the Virgin Hills Formation, Horse Spring, sample VHS-315.

DESCRIPTION: A damaged scale, less than $1 \mathrm{~mm}$ in length, with part of the base and neck not preserved. Unornamented, conically shaped crown possessing six primary ribs radiating from the apex, with the two anterior ribs bifurcating towards the crown base (Textfig. 3A). The posterior of the scale is complete and preserves a shallow neck separating the crown from the elliptical base that has a well-developed pulp canal surrounded by tubercular swellings. 
REMARKS: Scales attributed to $A$. seddoni are found along the northern margins of Gondwana (Yazdi and Turner 2000; Turner et al. 2002; Märss et al. 2007; Hairapetian et al. 2006; Trinajstic and George 2009) and their presence in mainly shallow-water facies indicate that they inhabited a near-shore, marine to marginal marine environment (Burrow 1997; Turner 1999; Märss et al. 2007). Within the Canning Basin, the majority of scales (46) have been recovered from the Virgin Hills Formation at Horse Spring (Trinajstic and George 2009; this work). This locality represents a distal slope environment formed in depths in excess of $200 \mathrm{~m}$ (Playford et al. 2009). This is in contrast to the high numbers (730) recovered from the shallow marine environment of the contemporaneous, Gneudna Formation, Carnarvon Basin, Western Australia (Turner and Dring 1981; Trinajstic 2001) and suggests that the scales were transported downslope, to deeper water prior to fossilization. This transport and likely consequential abrasion might have contributed to the lack of fine ornament, diagnostic for the taxon. However, as the co-occurring phoebodont teeth preserve the delicate lateral carinae and striations on the cusps, this explanation no longer seems likely for all scales. Another possibility for the absence of ornament is intraspecific variation, with both ornamented and non-ornamented scales present in shallow water facies at Hull Range (Chow et al. 2013).

\section{DISTRIBUTION AND STRATIGRAPHIC RANGE:} Associated conodont elements extend the upperknown age range of $A$. seddoni in the Canning Basin from $\mathrm{MN} 10 \mathrm{CZ}$ to $\mathrm{MN} 11 \mathrm{CZ}$. As the upper age of the Gneudna Formation type section is constrained by the remains of $A$. seddoni, the youngest age for the Gneudna may now be extended to MN $11 \mathrm{CZ}$. Outside Australia scales of $A$. seddoni have been reported in the Shishtu Formation, Shotori Range, eastern Iran and Chahriseh section, Esfahan, Central Iran from falsiovalis to rhenana $\mathrm{CZ}$ (= MN 1-10 CZ) (Yazdi and Turner 2000; Turner et al. 2002; Hairapetian et al. 2006).

Class Chondrichthyes Huxley, 1880 Subclass Elasmobranchii Bonaparte, 1838 Order Phoebodontiformes Ginter, Hairapetian and Klug, 2002

Family Phoebodontidae Williams, 1985 Genus Phoebodus St. John and Worthen, 1875

TYPE SPECIES: Phoebodus sophiae St. John and Worthen, 1875
Phoebodus bifurcatus Ginter and Ivanov, 1992 (Text-fig. 3B-E)

1991. Phoebodus sp.; Ginter 1991; p. 74, pl. 8, figs $1-2$.

1992. Phoebodus bifurcatus sp. nov.; Ginter and Ivanov, p. 65-66, figs 4A-F, 5D-H, 6A.

1995a. Phoebodus bifurcatus Ginter and Ivanov, 1992; Ginter and Ivanov, pl. 1, figs 5-6.

1995. Phoebodus bifurcatus Ginter and Ivanov, 1992; Ginter, p. 61, fig. $1 \mathrm{~F}-\mathrm{G}$.

1995. Phoebodus bifurcatus Ginter and Ivanov, 1992; Turner and Youngquist, p. 390-391, fig. 1.

1995. Phoebodus bifurcatus Ginter and Ivanov, 1992; Wang and Turner, p. 65, pl. 7, fig. 7.

2009. Phoebodus bifurcatus Ginter and Ivanov, 1992; Trinajstic and George, p. 648, pl. 1, fig. 9.

2010. Phoebodus bifurcatus Ginter and Ivanov, 1992; Hairapetian and Ginter, p. 360-361, fig. 2B-C.

MATERIAL: Six teeth from the Virgin Hills Formation, Horse Spring, samples VHS-308, VHS-310, VHS-311, VHS-315.

DESCRIPTION: Teeth with three lingually inclined cusps bearing a thin, lateral carinae extending from the bases of the cusps to the apices and lacking a distinct neck between the base and crown (Text-fig. 3B-E). The cusps are generally of nearly equal size however the size of the central cusp is significantly reduced in one specimen (WAM 14.8.2, Text-fig. 3D). The base is characterised by a labially directed semicircular arch which defines the lingual border and varies between specimens from strongly (Text-fig. 3C) to weakly bifurcated (Text-fig. 3E). A distinct button is lacking on most specimens, although a rounded thickening, close to the lingual rim is sometimes present (Text-fig. 3E). A large foramina is located in the centre of the lingual arch and in some specimens there are smaller adjacent canal openings.

REMARKS: The teeth typical of Phoebodus bifurcatus Ginter and Ivanov, 1992 are characterised by having five ornamented cusps and a bifurcating base with a distinct button surrounded by foramina (Ginter and Ivanov 1992). However, tricuspid forms, lacking intermediate cusplets, are known from the Confusion Range, Utah, USA and were attributed to juveniles (Turner and Youngquist 1995). Within the Canning Basin only tricuspid forms of $P h$. bifurcatus have been identified but were previously attributed to juvenile sharks based on deeply bifurcated bases, an indistinct button and lack of ornament on the cusps (Trinajstic and George 2009, 
pl. 1, fig. 9). The teeth attributed to juvenile individuals have been found in association with adult forms in the South Urals, Holy Cross Mountains and central Iran (Ginter and Ivanov 1992; Hairapetian and Ginter 2010) whereas in the Confusion Range, Utah, USA and the Canning Basin only juvenile teeth have been reported. Here we question the assignment of these tricuspid teeth to juvenile sharks as the size of some deeply bifurcated, tricuspid teeth (Text-fig. 3C-D, measuring up to $1.2 \mathrm{~mm}$ from furthest point on the lingual margin of the base to the labial edge), recovered from Horse Spring, are of comparable or larger size than other teeth attributed to adult forms previously reported (Ginter and Ivanov 1992, fig. 4B-F)). It is also unlikely that these larger teeth are symphyseal due to the asymmetry of the base and crown on one specimen (WAM 14.7.4, Textfig. 3C). This would leave the possibility that the Canning Basin teeth, and potentially other smaller tricuspid teeth, represent sexual dimorphism (e.g. Peyer 1968; Bass et al. 1973; Pfeil 1983; Straube et al. 2008), a sub species of Ph. bifurcatus, intraspecific variation or even a separate, closely related species.

DISTRIBUTION AND STRATIGRAPHIC RANGE: In the Canning Basin, Australia Ph. bifurcatus has only been recorded from MN $11 \mathrm{CZ}$; within the Holy Cross Mountains, Poland, South Urals, Russia, southern China and Utah, USA $P$ h. bifurcatus ranges from MN 11-12 CZ; in Kale Sardar, eastern Iran the range extends from the rhenana-lower linguiformis Zones (MN 11-13b CZ).

Phoebodus fastigatus Ginter and Ivanov, 1992 (Text-fig. 3D-F)

1973. Phoebodus floweri Wells, 1944; Gross, p. 131, pl. 35, fig. $7 \mathrm{a}-\mathrm{b}$.

1990. Phoebodus limpidus sp. nov.; Ginter, p. 75-76, pl. 4, fig. $6 \mathrm{a}-\mathrm{b}$.

1992. Phoebodus fastigatus sp. nov.: Ginter and Ivanov, p. 66-67, fig. 3A-B, G.

1993. Phoebodus sp.: Liszkowski and Racki, fig. 3F, H, K.

1995. Phoebodus fastigatus Ginter and Ivanov, 1992; Ginter, p. 59, fig. 1C-D.

1995. Phoebodus aff. fastigatus Ginter and Ivanov, 1992; Wang and Turner, p. 65, pl. 7, fig. 6.

1997. Phoebodus cf. Ph. fastigatus Ginter and Ivanov, 1992; Turner, p. 112-113, figs 4, 11, 12.

1998. Phoebodus fastigatus Ginter and Ivanov, 1992; Kaufmann, pl. 13, figs 1-4.

2000. Phoebodus fastigatus Ginter and Ivanov, 1992; Ginter and Ivanov, p. 327, pl. 1, fig. E.
2003. Phoebodus fastigatus Ginter and Ivanov, 1992; Aboussalam, pl. 27, figs 13-16.

2004. Phoebodus fastigatus Ginter and Ivanov, 1992; Ginter, fig. $2 \mathrm{H}-\mathrm{J}$.

2004. Phoebodus fastigatus Ginter and Ivanov, 1992; Hampe et al., p. 494-495, fig. 5.

2007. Phoebodus fastigatus Ginter and Ivanov, 1992; Liao et al., p. 173. fig. 3A-M.

2008. Phoebodus fastigatus Ginter and Ivanov, 1992; Ginter et al., p. 170, text-fig. 2E-H.

2009. Phoebodus fastigatus Ginter and Ivanov, 1992; Trinajstic and George, p. 649-650, fig. pl. 1, figs 11-16.

MATERIAL: Fourteen teeth from Virgin Hills Formation, Horse Spring, samples VHS-310, VHS-311, VHS-312 and VHS-315.

DESCRIPTION: Teeth with three main cusps. The medial cusp is approximately a third of the length of the lateral cusps and one half to one third the size at the base of the lateral cusps (Text-fig. 3F-H). When present, the accessory cusps are reduced in size, approximately half the size of the central cusp. The lateral cusps are long and slender with some specimens bearing slight torsion (Text-fig. 3F). The central and lateral cusps are all rounded in cross section (Text-fig. 3G), however, the labial faces of the cusps vary between teeth from smooth (Text-fig. 3H) to ornamented with faint to strongly developed striations (Text-fig. 3F). The base is rectangular to trapezoidal in outline, extending further mesio-distally than labio-lingually and bearing a straight to slightly convex thin lingual edge. The lingual face of the base is perforated by numerous small foramina with a round to slightly ovoid centrally located button (Textfig. $3 \mathrm{~F})$.

REMARKS: The teeth are attributed to Phoebodus fastigatus Ginter and Ivanov, 1992 based on the thin elongate lingual base with a straight lingual margin and centrally located ovoid button (Ginter and Ivanov 1992). The tooth crowns vary from the diagnostic thin elongate recurved lateral cusps (Text-fig. 3F-G) to shorter more robust cusps with less distal divergence (Text-fig. $3 \mathrm{H}$ ). A smooth labial cusp face is described as a diagnostic feature of Ph. fastigatus (Ginter and Ivanov 1992, 2000) and one of the features distinguishing it from $P h$. bifurcatus. This feature is not present in all teeth from the Canning Basin with faint to coarse cristae observed here and on teeth previously described by Trinajstic and George (2009, pl. 1, figs 11-16). As there is no correlation between tooth size and the presence of or lack of ornament, these differences are attributed to intraspecific variation rather than ontogeny. 


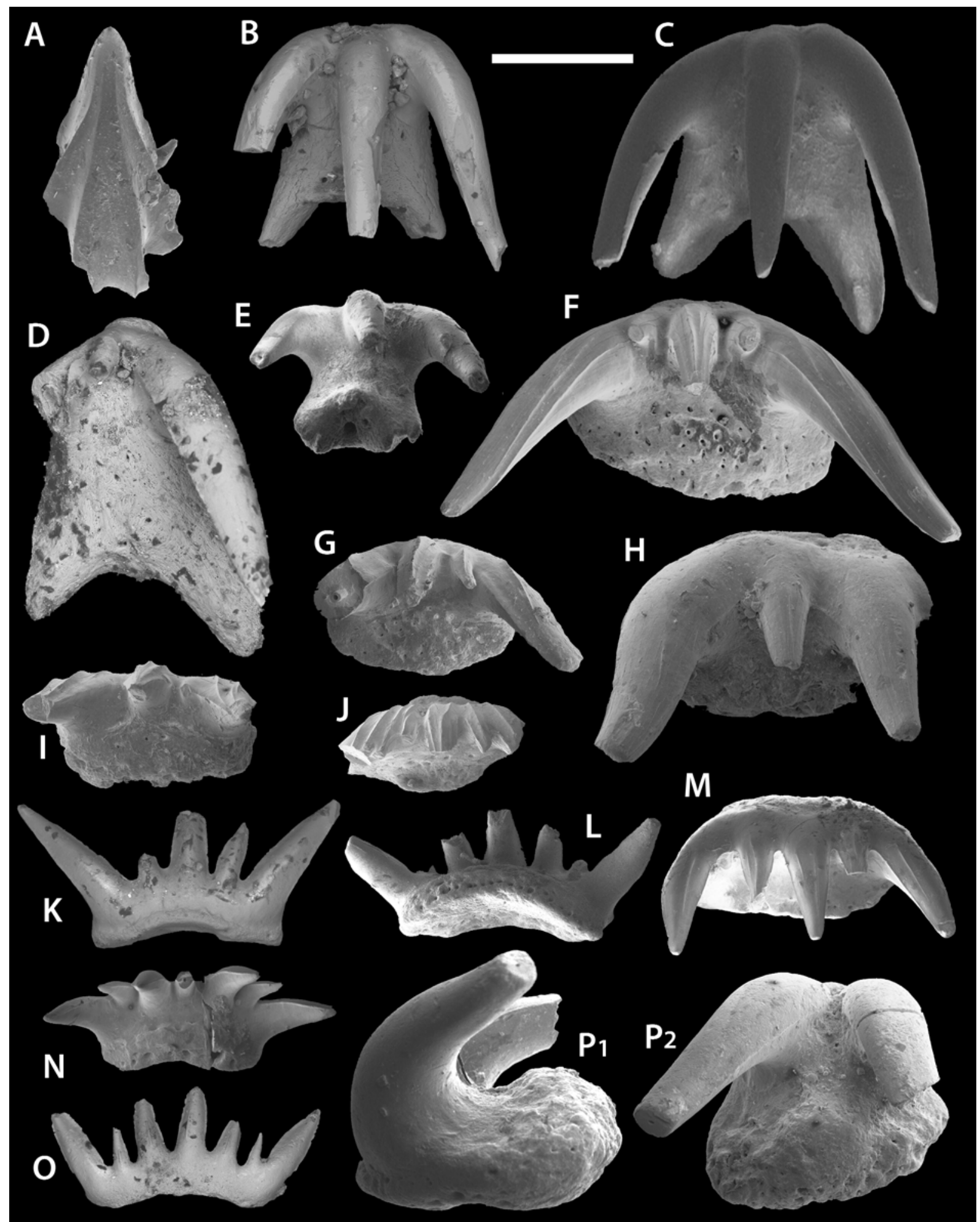

Text-fig. 3. Late Frasnian phoebodonts from the Virgin Hills Formation, Horse Spring, Canning Basin, Western Australia. A - Australolepis seddoni scale, WAM 14.7.3, sample VHS-315, in crown view; B-E, Phoebodus bifurcatus teeth in occlusal view. B - WAM 14.8.1, sample VHS-315; C - WAM 14.7.4, sample VHS-310; D - WAM 14.8.2, sample VHS-315; E - WAM 14.7.5, sample VHS-310. F-H, Phoebodus fastigatus teeth in occlusal view. F - WAM 14.7.9, sample VHS-311; G - WAM 14.7.11, sample VHS-312; H - WAM 14.7.10. I-J, Phoebodus cf. fastigatus in occlusal view. I - WAM 14.8.5, sample VHS-311; J - WAM 14.7.12, sample VHS 310. K-O, Phoebodus latus. K - WAM 14.8.3, sample VHS-312, in labial view; L - WAM 14.7.7, sample 311, in occlusal view; M - WAM 14.7.8, sample 312, in lingual view; N-WAM 14.9.13, sample VHS-312, in occlusal view; O - WAM 14.8.4, sample 311, in labial view; P- Phoebodus sp. 1 WAM 14.7.6, in lateral and occlusal views. Scale bar 0.5 mm 
DISTRIBUTION AND STRATIGRAPHIC RANGE: This species ranges from MN 6-11 CZ in the Canning Basin, Western Australia. Worldwide the range is greater, from the Givetian to Frasnian rhenana $\mathrm{CZ}$ in the USA, Morocco, Mauritania, Spain, Poland, China, Russia and eastern Australia.

\section{Phoebodus cf. fastigatus (Ginter and Ivanov 1992)}

(Text-fig. 3I-J)

MATERIAL: Three teeth from the Virgin Hills Formation, Horse Spring, sample VHS-312.

DESCRIPTION: Three small teeth, measuring less than $0.5 \mathrm{~mm}$ mesiodistally across the base, with damage to both the cusps and bases (Text-fig. 3I-J). Crowns with three to five lingually inclined cusps, comprising a main central cusp, two lateral cusps and, when present, smaller intermediate cusplets (Text-fig. 3J). The lateral cusps, when preserved, are slightly larger in size than the medial cusp and in one specimen show torsion towards the apex of one lateral cusp (Text-fig. 3I). When present, the intermediate cusps are small and fused to the base of the mesial margin of the lateral cusps. Prominent striations are present on the labial faces of the cusps, whereas the lingual faces are smooth. The base forms a roughly rectangular to trapezoid outline and is perforated by numerous small foramina. A rounded oval button is often difficult to determine on most specimens, however a faint outline can be seen, positioned centrally on one specimen (Text-fig. 3I).

REMARKS: The teeth described here are too poorly preserved for a definitive diagnosis, however they share similarities to the teeth attributed to the ornamented forms of Ph. fastigatus in this work. When preserved, the lingual margin of the base in $P h$. cf. fastigatus is thin; a diagnostic feature of $P h$. fastigatus (Ginter and Ivanov 1992), however, the cusps of $P h$. cf. fastigatus are ornamented with strong striations, ovoid in cross section and lack a distinct rounded button. The bases are not well enough preserved for an outline to be determined. Despite poor preservation, in one specimen the base appears lingually narrow (Text-fig. 3I). The teeth described here are consistently smaller than other teeth attributed to Ph. fastigatus and this may be evidence of ontogenetic variation. Furthermore the teeth commonly lack a distinct button, a feature attributed to juvenile forms in both Phoebodus gothicus Ginter, 1990 and Phoebodus bifurcatus (Ginter and Ivanov 1992). One tooth (WAM 14.7.10, Text-fig. 3G) may represent an intermediate form between teeth desig- nated Ph. fastigatus and the smaller teeth of Ph. cf. fastigatus as it possesses an elongate lateral cusp and more prominent ovoid button similar to Ph. fastigatus, but exhibits the coarse cristae and smaller size of $P h$. cf. fastigatus. Therefore an ontogenetic series is supported by the presence of this transitional form.

Phoebodus latus Ginter and Ivanov, 1995a

(Text-fig. 3K-O)

1992. Phoebodus sp. A Ginter and Ivanov 1992, p. 70, fig. $7 \mathrm{~A}-1$.

1993. Phoebodus sp. Liszkowski and Racki, p. fig. 5L-M.

1995a. Phoebodus latus sp. nov.; Ginter and Ivanov, p. 355, pl. 1, figs 3, 4 .

1995b. Phoebodus latus Ginter and Ivanov, 1995b; Ginter and Ivanov, p. 19, fig. 1.

1995. Phoebodus latus Ginter and Ivanov, 1995b; Ginter, fig. $1 \mathrm{E}$.

2009. Phoebodus latus Ginter and Ivanov, 1995b; Trinajstic and George, pl. 1, figs 18, 19.

2011. Phoebodus latus Ginter and Ivanov, 1995b; Ivanov and Lucas, fig. 2A, B.

MATERIAL: Eight teeth from the Virgin Hills Formation, Horse Spring, samples VHS-310 VHS-311 and VHS-312.

DESCRIPTION: The teeth here attributed to Phoebodus latus Ginter and Ivanov, 1995a are highly variable with three different morphotypes identified here. The first morphotype (Text-fig. $3 \mathrm{~K}-\mathrm{L}$ ) comprises five to seven smooth and almost straight conically shaped cusps with well-developed lateral carinas. The cusps diverge from the centre of the crown, which is defined by a central cusp with a base approximately $25 \%$ smaller than the base of the two lateral cusps (Text-fig. $3 \mathrm{~K}-\mathrm{L}$ ). A pair of intermediate cusplets, slightly smaller than the medial cusp, are present on all specimens. One specimen (WAM 14.7.7, Text-fig. 3L) exhibits a second pair of small broken cusplets fused at the base of the lateral cusps. The base is roughly trapezoidal in outline, thickened along the lingual edge and slightly arched. A faint outline of an ovoid button is preserved.

A single, well preserved tooth represents the second morphotype (Text-fig. 3M). The crown comprises three main cusps of almost equal size with a pair of intermediate cusplets approximately a third of the length of the lateral cusps. The cusps are ovoid in cross section and all lingually directed, with the medial and lateral cusps extending beyond the lingual margin of the base (Text-fig. 3M). The cusps exhibit a well-defined lateral 
carina as well as striations on the labial faces. The lingual faces of the cusps are smooth. The base forms a roughly rectangular outline with the very faint outline of a centrally located ovoid button. Morphotype three (Text-fig. 3N-O) is characterised by three main cusps and two pairs of intermediate cusplets, all of which are smooth with well-developed lateral carinas and a slight lingual inclination. The size of the central cusp ranges from small (Text-fig. 30), with the basal width approximately half of the size of the first intermediate cusplets, to significantly larger (Text-fig. $3 \mathrm{~N}$ ), almost the same size as the lateral cusps. The second pair are approximately half the size of the intermediate cusplets. The base is arched and slightly bifurcated (Text-fig. $3 \mathrm{~N}$ ) along the lingual rim which is also perforated by a horizontal row of foramina. The mesio-distally elongate button is positioned toward the edge of the lingual rim of the base (Text-fig. 3N).

REMARKS: The crown morphology of Phoebodus latus Ginter and Ivanov, 1995a is highly variable with the presence of intermediate cusplets greater than other known species attributed to Phoebodus (Ginter 2008). The third morphotype (Text-fig. 3N-O) resembles other Ph. latus teeth recovered from the South Urals, Russia and the Holy Cross Mountains, Poland (Ginter and Ivanov 1992, fig. 7A). The tooth also bears strong resemblance to another tooth from Horse Spring, previously described by Trinajstic and George (2009, pl. 1. figs 18, 19). The first and third morphotypes identified here lack the ornament on the labial faces of the cusps (Text-figs $3 \mathrm{~K}, \mathrm{O}$ ) seen in other examples of $\mathrm{Ph}$. latus (Ginter and Ivanov 1995a). The crown of the second morphotype more closely resembles other teeth from $P$ h. latus (Text-fig. $3 \mathrm{M}$ ) with the presence of three almost equally sized main cusps ornamented with ridges on the labial faces. However the base does not show the diagnostically distinct ovoid button positioned close to the lingual rim (Text-fig. 3M). There appears to be a great deal of diversity attributed to $P h$. latus that would suggest a high degree of heterodonty. Until more specimens are found, it is difficult to determine whether the teeth attributed to $P h$. latus in the Canning Basin are products of heterodonty or if they represent intraspecific variation.

DISTRIBUTION AND STRATIGRAPHIC RANGE: Within the Canning Basin, the range of this species is confined to MN 9-11 CZ. In other regions, the species is longer ranging, from the falsiovalis to linguiformis conodont Zones (MN 1-13b) in Poland, the Middle and South Urals, and Timan of Russia.

\section{Phoebodus sp. 1 \\ (Text-fig. 3P)}

MATERIAL: One tooth from the Virgin Hills Formation, Horse Spring, sample VHS-312.

DESCRIPTION: A robust tooth comprising two lingually inclined, almost equally sized laterally diverging cusps, which are rounded in cross section and bear a single faint lateral carina on the inner face (Text-fig. $\left.3 \mathrm{P}_{1-2}\right)$. There is no evidence of a third cusp forming. The base is asymmetric and perforated by numerous pores concentrated along the basal $\operatorname{rim}\left(3 \mathrm{P}_{2}\right)$. The base is thickest along the lingual rim, forming a rounded bulbous edge. A well-defined circular button is located centrally on the base and reaches almost to the lingual edge. A rounded, striated labiobasal thickening extends from the base (Text-fig. $3 \mathrm{P}_{1}$ ).

REMARKS: The thin, smooth cusps, which are rounded in cross section, and the centrally located spherical button are similar to the morphological features that diagnose Ph. fastigatus (Ginter and Ivanov 1992, fig. 3A-B). In addition, the tooth shares a similar cusp morphology to teeth from the same horizon, attributed to Ph. fastigatus (Text-fig. 3H). However, the bicuspid crown, asymmetric outline of the base and thickened lingual rim makes an accurate diagnosis problematic. It is suggested that these differences are pathological, and that the tooth is most likely from $P h$. fastigatus. However, as less than $1 \%$ of chondrichthyan teeth, both fossil and extant (Becker et al. 2000) are known to exhibit pathology the diagnosis of $P h$. fastigatus cannot be confirmed and until further teeth are recovered this tooth is placed in open nomenclature.

Genus Thrinacodus St. John and Worthen, 1875

TYPE SPECIES: Thrinacodus nanus St. John and Worthen, 1975

Thrinacodus tranquillus Ginter, 2000

(Text-fig. 4A-C

2000. Thrinacodus tranquillus sp. nov.; Ginter, p. 374-377, figs $2 \mathrm{a}-\mathrm{c}, 3 \mathrm{a}-\mathrm{f}, 4 \mathrm{a}-\mathrm{c}, 5 \mathrm{~h}-\mathrm{k}$.

2000. Thrinacodus cf. ferox (Turner); Long and Hairapetian, p. $214-216$, fig. $4 \mathrm{n}$.

2002. Thrinacodus tranquillus Ginter, 2000; Ginter et al., p. 186-188, text-fig. 9f-h, pl. 2, fig. h, pl. 3, fig. h, pl. 11 , figs $\mathrm{h}-\mathrm{I}$. 
2008. Thrinacodus tranquillus Ginter, 2000; Derycke et al., p. 988 , text-fig. $4(1-2)$.

2009. Thrinacodus tranquillus Ginter, 2000; Hairapetian and Ginter, p. 191, text-fig 9c-d.

2010. Thrinacodus tranquillus Ginter, 2000; Ginter et al., p. 41 , fig. $33 \mathrm{~A}$.

2010. Thrinacodus tranquillus Ginter, 2000; Ginter and Turner, p. 1668, fig. 2C.

MATERIAL: Four teeth from the Virgin Hills Formation, Casey Falls, samples CF-127.5 and CF-471; ten teeth from the Bugle Gap Limestone, Casey Falls, samples 1984-97 and 1984-98.

DESCRIPTION: A total of three morphotypes are attributed to Thrinacodus tranquillus in this work. The first morphotype (Text-fig 4A), is the most common and features a symmetrical crown with three sub-equal cusps, often with one dominant lateral cusp. When preserved, the lingually extended base is positioned asymmetrically in relation to the crown. A centrally located canal is present on the occlusal face of the base, which also shows slight torsion towards the distal end.

The second morphotype (?symphyseal teeth sensu Ginter 2000; symphyseal tooth Ginter pers comm.), represented by a single tooth (Text-fig. 4B), comprises a symmetrical crown with three thin, straight, equally sized and lingually directed cusps, each with lateral carinae and faint striations on the labial face. The base is thin, extends lingually further than the cusp apices and bears a small nutritive canal approximately half way down the occlusal face of the base. There is no obvious sign of torsion towards the end of the base.

The third morphotype is represented by a single asymmetric tooth (WAM 14.7.29, Text-fig. 4C) that is characterised by a crown consisting of three unequal cusps. The straight, lingually directed central cusp is preserved with lateral carinae and faint striations on the labial face. The thin base extends further lingually than the apex of the central cusp and is curved distally in relation to the crown. The posterior end of the base is contorted toward a vertical orientation with a small nutritive canal located approximately half way down the occlusal face.

REMARKS: These teeth largely conform to the diagnosis of Thrinacodus tranquillus Ginter, 2000, and the differences between the tooth forms are attributed to heterodonty. Previous work (Ginter 2000; Ginter et al. 2002; Duncan 2003; Ginter and Turner 2010) has suggested the presence of two tooth types; the first with a flattened base positioned asymmetrically in relation to the crown and a smaller almost completely sym- metrical form (Duncan 2003). The first morphotype (Text-fig 4A) is the most common tooth form attributed to Th. tranquillus and has been reported from various locations across northern Gondwana (Ginter and Turner 2010). The second, smaller morphotype (Textfig. 4B), which has had its assignment to Th. tranquillus recently questioned (Ginter and Turner 2010), is less common and with few examples recorded from the Montagne Noire (Ginter 2000). Based on reconstructions of tooth placement within thrinacodont jaws (Turner 1982; Ginter et al. 2002; Duncan 2003), the supposed symmetrical symphyseal teeth only comprise a small proportion of teeth thus likely lower yields of these teeth are to be expected.

A third morphotype (Text-fig. 4C) has been attributed to Th. tranquillus with similar teeth previously recorded from Montagne Noire and Oum El Jerane and Tizi Nersas, Morocco, conversely these specimens were designated Thrinacodus cf. ferox (Ginter 2000, fig. 2; Ginter et al. 2002, fig. 9A-E). It was suggested by Ginter et al. (2002) that the teeth of Th. cf. ferox may represent the lateral most teeth of Th. tranquillus, which was supported by the presence of intermediate forms between the typical teeth of Th. tranquillus and Th. cf. ferox. A similar variety of tooth forms is present in the Canning Basin, however the teeth are recovered from Late marginifera $\mathrm{CZ}$ dated deposits making their attribution to the Th. ferox unlikely as it is regarded as a late Famennian to late Tournaisian species (Ginter and Turner 2010).

DISTRIBUTION AND STRATIGRAPHIC RANGE: In the Canning Basin this species is recorded from the Late marginifera $\mathrm{CZ}$. A similar age rhomboidea or Late marginifera $\mathrm{CZ}$ is recorded for Chahriseh, Iran (Long and Hairapetian 2000; Ginter et al. 2002; Hairapetian and Ginter 2009) and also a marginifera CZ for Hunan, China (Lelièvre and Derycke 1998). In Oum El Jerane and Tizi Nersas, Morocco this species ranges from rhomboidea or Late marginifera $\mathrm{CZ}$ to Middle to Late expansa (Ginter et al. 2002; Derycke et al. 2008). Younger known occurrences have been recorded from the Late trachytera CZ, Holy Cross Mountains, Poland, Lower to upper expansa CZ, Thuringia, Germany and expansa $\mathrm{CZ}$ in Montagne Noire. Within the South Urals the range of this species is recorded from the Late expansa to Early praesulcata CZ (Ivanov 1996).

Genus Diademodus Harris, 1951

TYPE SPECIES: Diademodus hydei Harris, 1951 
Diademodus dominicus sp. nov. (Text-fig. 4D-E)

ETYMOLOGY: In honour of Mr Dominicus 'Tim' Mueller, M.Sc., who guided the careers of many aspiring geoscientists.

HOLOTYPE: Specimen WAM 14.7.1 from the Virgin Hills Formation, Horse Spring, Canning Basin, Western Australia; sample VHS-310; Frasnian, MN 11 CZ; Text-fig. 4D.

MATERIAL: Two teeth from the Virgin Hills Formation, Horse Spring, sample VHS-310.

DIAGNOSIS: Teeth with a multicuspid phoebodont type crown comprising three cusps and three to four pairs of intermediate cusplets (Text-fig. 4D). The cusps are thin and ovoid in cross section, becoming circular towards the cusp apex and bearing prominent lateral carinae. A slight lingual inclination is present on all cusps with the larger lateral cusps recurving occlusally. The base is highly arched, trapezoid in outline and becoming narrower labially (Text-fig. $4 \mathrm{E}_{2}$ ). The labial margin is rounded and perforated by a row of foramina. A mesiodistally elongate hump occupies the majority of the basolabial shelf with the labial margin abutting the base of the cusps. There is a slight decrease in height of the shelf towards the lingual margin.

DESCRIPTION: Distinctive teeth with symmetrical crowns that fan out mesiodistally and comprise three mains cusps and three to four pairs of lateral cusps (Text-fig. 4D-E). The medial cusps are broken in both specimens, however the bases are approximately half the width of the lateral cusps. A pair of small, first lateral cusplets are independent of the medial cusp but are fused at the base with the second lateral cusplets which are slightly smaller in size than the lateral cusps. In one holotype (WAM 14.7.1, Text-fig. 4E) a small fourth cusplet is present and erupts from the base of the lateral cusp. The preserved cusps appear ovoid in cross section (elongate labio-lingually), at the base and exhibit smooth lingual and labial faces with well-developed lateral carinae. No discernible crown-base interface is present on the labial faces of the teeth. The base

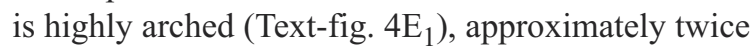
as long mesiodistally as it is labiolingually (Text-fig. $4 \mathrm{E}_{2}$ ). A roughly trapezoid to almost rectangular shape of the base can be determined, with rounded lingual corners. A row of foramina is present running along the lingual rim. An ovoid button is positioned centrally on the base extending between the third lateral cusplets and gradually dissipates towards the lingual margin of the base. The labial face of the button preserves the openings to a row of canals and terminates abruptly, close to the base of the crown.

REMARKS: The teeth of the type specimen Diademodus hydei Harris, 1951 are partially obscured in matrix thus similarities to the genus are based on the visible labial tooth face of Diademodus hydei as well as comparison to the other member of this genus, Diademodus utahensis Ginter, 2008. The teeth of Diademodus all share the typical phoebodont tooth crown but can be differentiated on the number of intermediate cusplets (Ginter 2008). The cusp arrangement and variation in cusplet size present in D. dominicus sp. nov. (Text-fig. 4E) is similar to D. utahensis (Ginter 2008, fig. 1B) and differs from the original description of $D$. hydei which was figured having two prominent central cusps and intermediate cusplets of almost equal size (Harris 1951, fig. 3b), however, reinterpreted by Ginter (2008) as possessing a single prominent central cusp. The teeth of $D$. dominicus sp. nov. are further distinguished as some cusplets are fused at the base with the adjacent cusp or cusplets, a feature not apparent in $D$. hydei or D. utahensis. The lingual face of teeth from $D$. dominucus sp. nov. most closely resemble those of $D$. hydei as these teeth lack both the mesiodistal extension of the base beyond the crown as well as the presence of a basolabial shelf, features both present in D. utahensis. The tooth is distinguished from both $D$. hydei and $D$. utahensis by a shorter mesiodistal length of the base which is also significantly arched. The basal outline of $D$. dominicus sp. nov. narrows lingually and is substantially different from that of $D$. utahensis which forms a trapezoid shape becoming wider lingually and slightly compressed centrally on the lingual margin. The orolingual hump of $D$. dominicus sp. nov. is also far more prominent than that of $D$. utahensis. We believe these differences are significant enough for the establishment of the species Diademodus dominicus sp. nov.

Despite the low number of teeth recovered from $D$. utahensis and the obscured nature of teeth from $D$. hy$d e i$, heterodonty within each species is so far limited to variation in the number of intermediate cusplets, reported in D. utahensis (Ginter 2008) and D. dominicus sp. nov. Ginter (2008) suggests that anterior teeth of D. utahensis may be narrower and speculates they would be similar in form to teeth attributed to $P h$. fastigatus (in Ginter 2008, fig. 3B). This would appear more likely than the teeth of $D$. dominicus sp. nov. representing anterior $D$. utahensis teeth as the base and cusp morphology is far more similar between $D$. utahensis and the Ph. fastigatus tooth examples. 
Order Symmoriida Zangerl, 1981

Family Stethacanthidae Lund, 1974

Genus Stethacanthus Newberry, 1889

TYPE SPECIES: Physonemus altonensis St. John and Worthen, 1875.

\section{Stethacanthus sp. 1 \\ (Text-fig. 4F-G)}

MATERIAL: One tooth from the Virgin Hills Formation, Casey Falls, sample CL-471; one tooth from the Bugle Gap Limestone, Casey Falls, sample 1984-97.

DESCRIPTION: Small teeth, less than $1 \mathrm{~mm}$ mesiodistally and consisting of a slender prominent central cusp and two smaller, slightly diverging lateral cusps approximately one third of the size of the medial cusp (Text-fig. $\mathrm{F}-\mathrm{G}_{1}$ ). A pair of small intermediate cusplets is present with one specimen possessing a second pair of cusplets on the distal side of the lateral cusps (Textfig. $4 \mathrm{~F}_{1-2}$ ). Thin vertical striations extend from the base to tip on the lateral and intermediate cusps on the well preserved cusps. The base forms a distinct triangular outline (Text-fig. $\mathrm{G}_{2}$ ), extending beyond the crown mesio-distally with rounded edges and a low profile. The apex of the lingual projection on the base is slightly thickened and possesses multiple foramina along the lingual rim.

REMARKS: The teeth described here possess characters found in other stethacanthid tooth types including upright, unconnected cusps ornamented in sub-parallel cristae and a base lacking a labial depression. The triangular shaped lingual extension of the base (Text-fig. $4 \mathrm{G}_{2}$ ) is a common feature of Moroccan stethacanthid teeth (Ginter et al. 2002, pl. 10C) and also seen in other Famennian teeth from the Montagne Noire (Ginter 2000, fig 7C) and Dalmeh, Iran (Long and Hairapetian 2000, fig 41). The teeth from the Canning Basin also appear to exhibit a thickening around the lingual apex of the base, which is similar to a tooth from Dalmeh, Iran (Long and Hairapetian 2000, fig. 4e) but lack a well-formed labial boss. One tooth variant (WAM 14.7. 26, Text-fig. 4F) exhibits a sixth cusp, a feature not usually found in Famennian stethacanthid teeth from Morocco and Iran (Ginter et al. 2002). Further specimens are required to determine if this tooth represents a nontypical variant of Stethacanthus sp. 1 or if there is a degree of heterodonty within this species.

\section{Order Ctenacanthiformes Glikman, 1964 \\ Family Ctenacanthidae Dean, 1909 \\ Genus Cladoides Maisey, 2001}

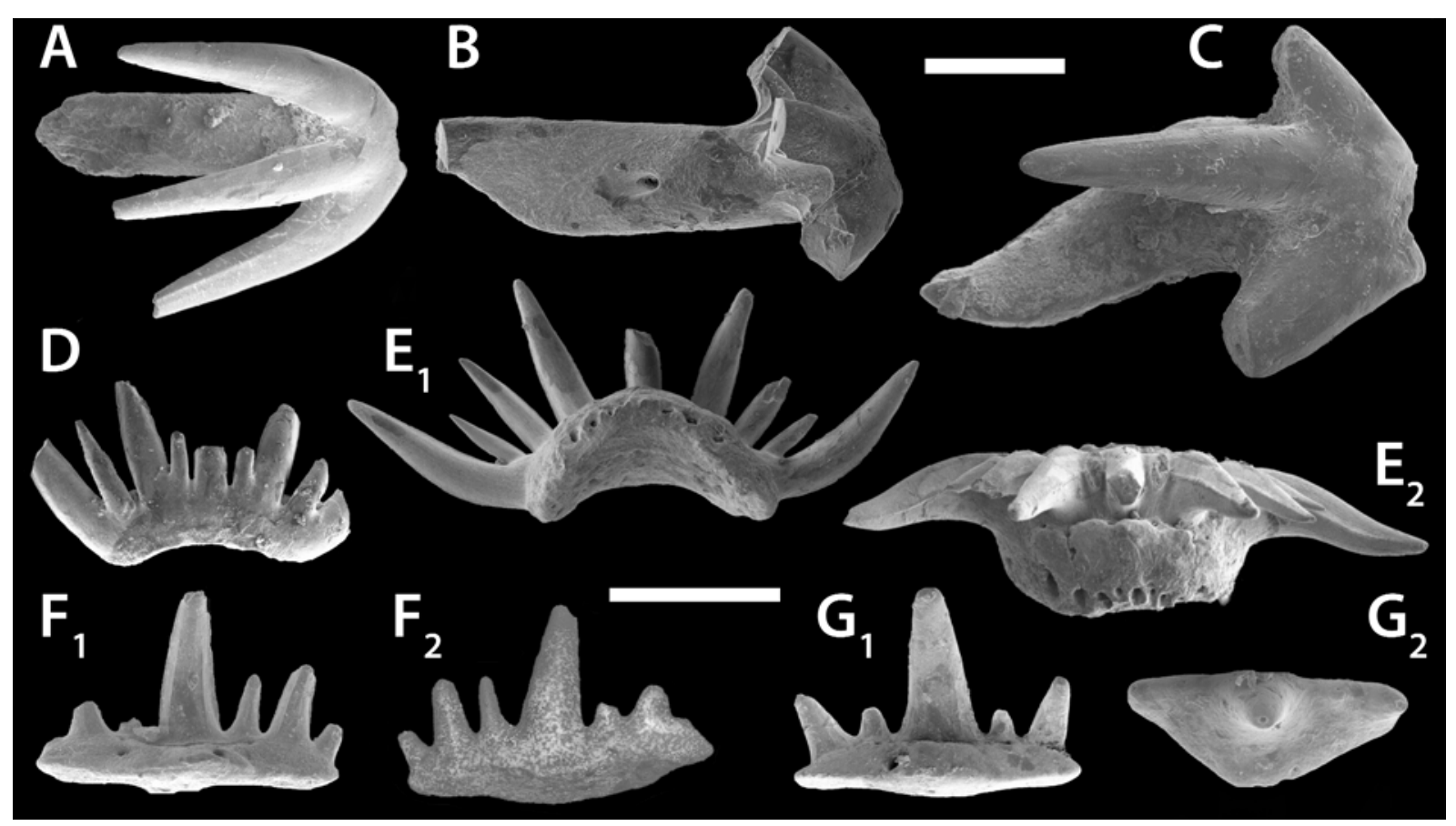

Text-fig. 4. Shark teeth from the middle Famennian at Casey Falls (A-C, F-G) and Upper Frasnian at Horse Spring (D-E). A-C, Thrinacodus tranquillus in occlusal view. A - WAM 14.7.15, sample 1984-97; B - WAM 14.7.16, sample 1984-97; C - WAM 14.7.29, sample 1984-98. D-E, Diademodus dominicus sp. nov. teeth, sample VHS-310. D - WAM 14.7.2, in lingual view; E - WAM 14.7.1, holotype, in lingual and occlusal views; F-G - Stethacanthus sp. 1. F - WAM 14.7.26, sample Cl-471, in lingual and labial views; G - WAM 14.7.27, sample 1984-98 in lingual and occlusal views. A-E, scale bar $=0.5 \mathrm{~mm} ; \mathrm{F}-\mathrm{G}, \mathrm{scale}$ bar $=0.5 \mathrm{~mm}$ 
Cladodoides wildungensis Jaekel, 1921 (Text-fig. 5A)

1921. Cladodoides wildungensis sp. nov.: Jaekel, 1921.

1991. Stethacanthus sp.; Ginter, p. 75, pl. 8: 4, pl. 9: 2, 3.

1992. Cladodus cf. C. thomasi Turner; Ivanov et al., p. 89, pl. 36: $3,4$.

1992. Stethacanthus thomasii Turner [sic]; Derycke, p. 3940, fig. 14, pl. 2: 10, 11.

1995b. Stethacanthus $\mathrm{cf}$. thomasi Turner; Ginter, fig. 2A.

1996. "symmoriid with button partially divided"; Ginter and Ivanov, fig. 4C.

1996. "stethacanthid?"; Ginter and Ivanov, fig. 5C, D.

2000. Stethacanthus cf. thomasi (Turner); Ginter and Ivanov, pl. 1: J.

2002. Stethacanthus resistens sp. nov.; Ginter et al., figs 2, 3, 4C-I, 5C.

2010. Cladodoides wildungensis Jaekel; Ginter et al., fig. 66A-J.

MATERIAL: Two teeth from the Virgin Hills Formation, Horse Spring, sample VHS-310; Casey Falls, sample Cl-9.

DESCRIPTION: Symmetrical teeth with five lingually inclined and strongly diverging cusps. The central cusp is large, almost twice the width at the base of the lateral cusps (Text-fig. 5 $\mathrm{A}_{1}$ ). The intermediate cusps are significantly smaller, approximately half the height of the lateral cusps. Both the lingual and labial faces of the cusps are ornamented with sub parallel ridges. The base is ovoid in outline, slightly arched and elongated mesiodistally, extending beyond the crown. A small basiolabial projection is preserved on one tooth (Text-fig. $5 \mathrm{~A}_{2-3}$ ), between the distal edges of the medial cusp. Due to abrasion, only the remnants of a mesiodistally elongate button are preserved on both teeth. One tooth (Text-fig. $5 \mathrm{~A}_{1}$ ) preserves an outline of a button, extending the distance between the two intermediate cusps, as well as a series of grooves, presumably once pore canals running labiolingually.

REMARKS: Ginter et al. (2010) recognises two morphotypes of Cladodoides wildungensis Jaekel (1921). The first morphotype, characterised by its larger size and long, slender medial cusp; and the second smaller morphotype, to which the Canning Basin teeth are here assigned, that are less than two mm across the length of the base with diverging cusps ornamented in coarse sub-parallel cristae. The teeth described here are markedly similar to the holotype of $C$. wildungensis (figured in Ginter et al. 2010, fig. 661) as well as resembling teeth from Poland (Ginter et al. 2002, fig. 2C-
F) designated Stethacanthus resistens. Ginter et al. (2010) suggests that it is possible that some, if not all teeth previously attributed to Stethacanthus resistens belong to the $C$. wildungensis. If so, it appears $C$. wildungensis is considerably cosmopolitan in nature.

\section{DISTRIBUTION AND STRATIGRAPHIC RANGE:} This species ranges from MN $11 \mathrm{CZ}$ - lower crepida in the Canning Basin, Western Australia. Due to a degree of synonymy with $S$. cf. thomasi a definitive range is difficult to ascertain, however a range from the Upper Frasnian - middle Famennian is likely in Poland, Moravia, Germany, Morocco and Russia.

Ctenacanthiform gen. et sp. indet 1 (Text-fig. 5B)

MATERIAL: One tooth from the Napier Formation, South Oscar Range, sample SO-200.

DESCRIPTION: This highly symmetrical tooth is well preserved, by comparison to other teeth in the sample, and possesses five slender, lingually inclined cusps that fan out mesio distally (Text-fig. 5 $\mathrm{B}_{1-2}$ ). A large prominent central cusp is flanked by two smaller intermediate cusps. The lateral cusps are approximately two thirds the length of the medial cusp and diverge at approximately 45 degrees to the medial cusp. In labial view, the cusps appear more triangular and connected at the bases (Text-fig. 5 $\mathrm{B}_{3}$ ). All cusps are ovoid in cross section and ornamented on both the lingual and labial faces with strong vertical striations. The base is trapezoid in shape extending further lingually than labially and broadest along the lingual margin (Text-fig. $5 \mathrm{~B}_{2}$ ). The base is thickest in a trapezoid area between the labial edge of the lingual button and lateral cusps. A thin baso-labial projection is present with a row of foramina. A well developed, ovoid shaped button is positioned close to the lingual border and perforated by a row of four large foramina (Text-fig. 5B $\mathrm{B}_{1}$ ).

REMARKS: The tooth shares commonalities between many cladodont-like teeth outlined by Duffin and Ginter (2006). The connection of the tooth cusps by an enameloid or orthodentine layer (Text-fig. $5 \mathrm{~B}_{3}$ ) excludes this tooth from belonging to the symmoriids and stethcanthids. The tooth lacks a basiolabial depression as seen in Cladodus and Ctenacanthus and is thereby more similar to Cladoides which may also lack this feature. The baso-labial shelf is straight which is characteristic of Cladoides but is far more developed in Ctenacanthiforme gen. et. sp. indet 1 and this pro- 


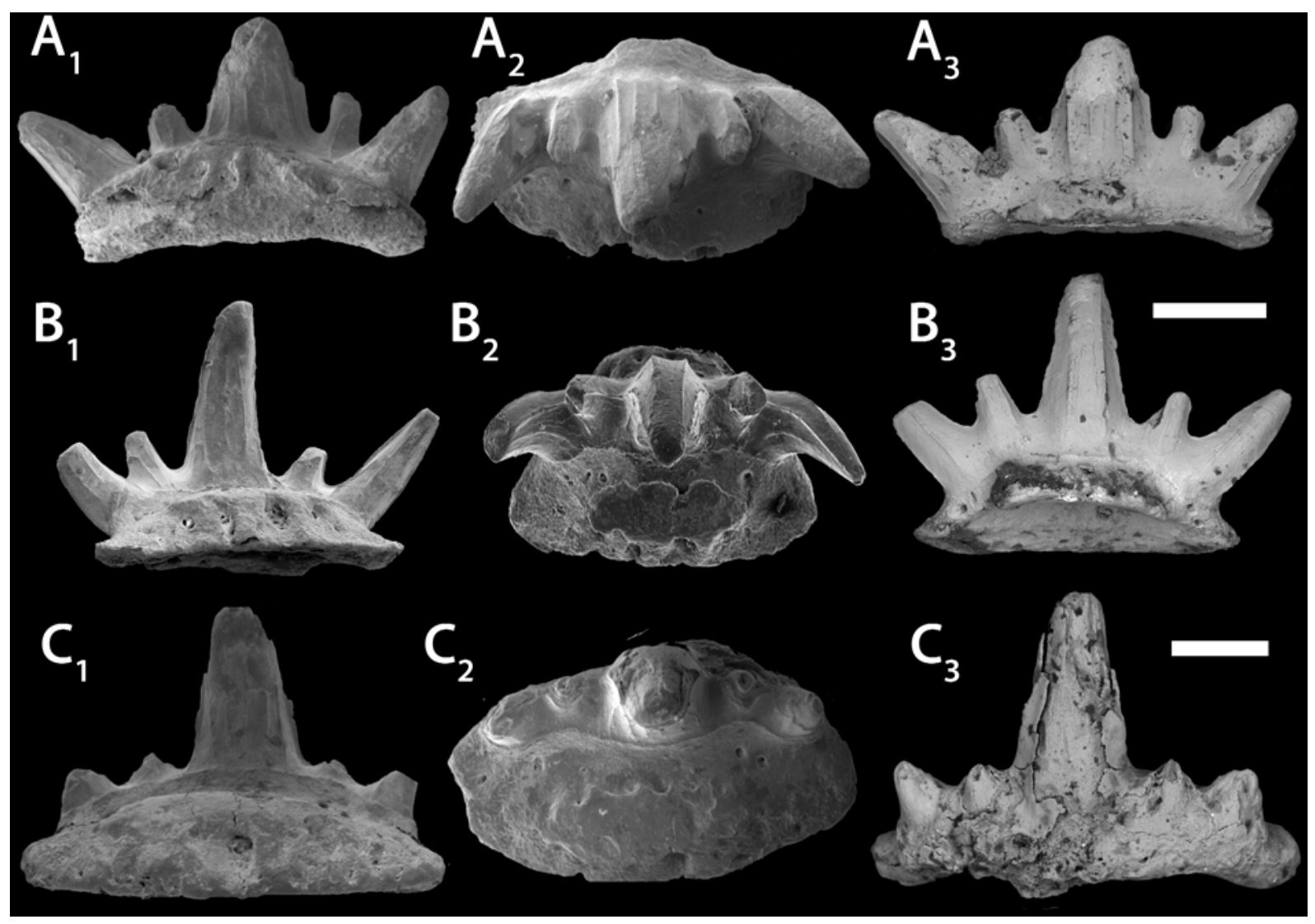

Text-fig. 5. Ctenacanthiform teeth from the Famennian at Casey Falls (A) and South Oscar Range (B-C). A - Cladoides wildungensis, WAM 14.7.14, sample CL-9, in lingual, occlusal and labial views. B - Ctenacanthiform gen. et. sp. indet 1, WAM 14.7.19, sample SO-200, in lingual, occlusal and labial views; C - Ctenacanthiform gen. et. sp. indet 2, WAM 14.7.20, sample SO-200, lingual, occlusal and labial views. A-B, scale bar = $0.5 \mathrm{~mm}$; C, scale bar $1 \mathrm{~mm}$

jection may obscure the presence of any basolabial depression. The tooth is differentiated from other Ctenacanthiformes based on the strongly rounded or biconvex central cusp and lateral cusps, which are almost two thirds the size of the central cusps. The tooth is referred to the Ctenacanthiformes, perhaps temporally, based on the orthodentine or enameloid connective tissue present between the cusps and similarities with the genus Cladoides.

Ctenacanthiform gen. et sp. indet 2

(Text-fig. 5C)

MATERIAL: One tooth from the Virgin Hills Formation, Casey Falls, sample 1984-97; one tooth from the Napier Formation, South Oscar Range, sample SO200.

DESCRIPTION: Heavily abraded teeth with a large medial cusp flanked by four smaller triangular shaped cusps consisting of a pair of small lateral cusps and a pair of intermediate cusplets approximately half the size of the lateral cusps (Text-fig. $5 \mathrm{C}_{1-2}$ ). The medial cusp is inclined slightly and convex along the lingual edge in cross section. Where the outer enameloid is preserved on the central cusp, faint vertical striations can be observed. The intermediate and lateral cusps do not show any ornamentation with the lateral cusps diverging at a 45 degree angle. A distinct rim is preserved on the labial face of the teeth and marks the crown base interface (Text-fig. $5 \mathrm{C}_{1-2}$ ). The base extends lingually almost three times the width of the crown and forms a large dome shape that extends beyond the crown mesiodistally (Text-fig. $5 \mathrm{~A}_{2}$ ). A very faint ovoid button, approximately twice as long as it is wide, is preserved on one specimen and positioned closer to the lingual margin than the crown (Text-fig. $5 \mathrm{~A}_{2}$ ). A series of foramina perforate the lingual face of the base with a single large nutritive canal positioned centrally along the lingual margin. The labial face of the base in both specimens is highly abraded (Text-fig. $5 \mathrm{~A}_{3}$ ), however remnants of a thickened baso-labial shelf and slight depression are present. 
REMARKS: These teeth have been attributed to the Ctenacanthiformes based on features shared with other members of this group. The prominent central cusp and diminished lateral and intermediate cusps are similar to Cladodus conicus Agassiz, 1843 although the base on the tooth from the Canning Basin specimens is much thicker and the striations preserved on the cusps are coarser. The central cusp is flattened along the labial face and exhibits a convex lingual face, and in this respect closely resembles Cladodus. The significant abrasion to the labial faces of the teeth does not allow further taxonomic refinement. The teeth do feature a unique rim running across the crown base interface that is not typically seen in other cladodont type teeth.

DISTRIBUTION AND STRATIGRAPHIC RANGE: Frasnian conodont Zone 13b to Late marginifera conodont Zone in the Canning Basin, Western Australia.

Cohort Euselachii Hay, 1902 Order indet.

Family Protacrontidae Zangerl, 1981

Genus Protacrodus Jaekel, 1925

TYPE SPECIES: Protacrodus vetustus Jaekel, 1925

Protacrodus serra Ginter, Hairapetian and Klug, 2002 (Text-fig. 6A-B)

1990. "Cladodus" sp.; Ginter, p. 77, pl. 4, fig. 9.

2000. Protacrodus cf. vetustus Jaekel; Ginter, p. 378-379, fig. 8.

2002. Protacrodus serra, sp. nov.; Ginter, Hairapetian and Klug, p. 195, text-fig. 11; pl. 2, figs L-N; pl. 11, figs. A-C.

2007. Protacrodus serra Ginter, Hairapetian and Klug, 2002; Gillis and Donoghue, p. 40, fig. d-e.

2007. Protacrodus cf. serra Ginter, Hairapetian and Klug, 2002; Ginter and Sun, p. 711, 4C.

2010. Protacrodus serra Ginter, Hairapetian and Klug, 2002; Ginter et al., p. 87, fig. 80A-C.

2011. Protacrodus serra Ginter, Hairapetian and Klug, 2002; Ginter et al., p. 168, fig. 10I-J.

MATERIAL: Two teeth from the Bugle Gap Limestone, Casey Falls, samples 1983-94; 1984-97.

DESCRIPTION: The teeth described here can be assigned to morphotype one of Protacrodus serra (Ginter et al. 2002, text-fig. $11 \mathrm{C}-\mathrm{E}$ ) and comprise asymmetrical crowns with three cusps directed distally to one side (Text-fig. 6A). The medial cusp is large, over twice the size of the lateral cusps with a narrow labiolingual profile. Both the lingual and labial faces of the cusps are ornamented in strong cristae. In one specimen (WAM 14.7.23, Text-fig. 6B), a row of small pointed cusplets is present along the crown base interface on the labial face. The base is narrow lingually, with a slightly extended and straight lingual rim (Text-fig. 6B) that is perforated by a large canal located centrally. The labial face of the base does not protrude and is perforated by a row of small foramina (Text-fig. $6 \mathrm{~A}_{2}$ ).

REMARKS: Evaluating variation present in the teeth of different shark taxa is difficult as odontological studies remain incomplete (Straube et al. 2008). The presence of labial cusplets (Text-fig. 6B) on P. serra may be evidence of intraspecific variation or the presence of sexually based heterodonty which is seen in the dentition of some fossil (Parmley and Cicimurri 2003) and extant shark species (Raschi et al. 1982). The same labial cusplets are apparent in other teeth attributed to P. serra from Iran (Ginter et al. 2002, pl. 2LM; Ginter et al. 2011, text-fig 10I-J), which rules out regional influences for variation. Cusplets also appear on teeth independent of size (Text-fig. 6A-B) and morphotype (Ginter et al. 2002, pl. 2L-M) which makes ontogenetic variation unlikely.

DISTRIBUTION AND STRATIGRAPHIC RANGE: This species has an older occurrence in the Canning Basin, Western Australia (Lower crepida to Upper marginifera Zone) as compared to other areas of the world where it occurs in the Early expansa Zone in Dalmeh, Iran, Late expansa Zone, Tizi and Oum El Jerane, Morocco and probable expansa Zone Khor Virap, Armenia. In China this species has been recorded from the middle Tournaisian. Another protacrodont species, $D$. masureae (Burrow et al. 2010) is known to range from the Late Devonian into the Carboniferous.

Genus Deihim Ginter, Hairapetian and Klug, 2002

TYPE SPECIES: Deihim mansureae Ginter, Hairapetian and Klug, 2002

Deihim mansureae Ginter, Hairapetian and Klug,

(Text-fig. 6C-D)

2000. ?Protacrodus sp. Long and Hairapetian, p. 217-218, fig. $4 \mathrm{O}$. 
2000. Protacrodus sp. cf. "P. aequalis" sensu Ginter and Turner; Yazdi and Turner, p. 226, figs 3.4-7, 4.4.

2002. Deihim mansureae gen. et sp. nov.; Ginter, Hairapetian and Klug, p. 191-193, text-fig. 10; pl. 1, fig. r; pl. 2, fig. k; pl. 4, figs F-G, J-M; pl. 5, figs A-M.

2005. Polycrodontidae insertae sedis Derycke-Khatir, p. 76, pl. VII, figs 7-10.

2005. Bobbodus sp. Derycke-Khatir, p. 95-96, pl. XII, figs $1-2$.

2009. Deihim mansureae Ginter, Hairapetian and Klug, 2002; Hairapetian and Ginter, p. 176, 179, fig. 2D, 4H.

2010. Deihim mansureae Ginter, Hairapetian and Klug, 2002; Hairapetian and Ginter, p. 362, fig. 3A.

2010. Deihim mansureae Ginter, Hairapetian and Klug, 2002; Ginter et al., p. 88, fig. 81A-J.

2011. Deihim mansureae Ginter, Hairapetian and Klug, 2002; Ginter et al., p. 166, 169, 8A-E, 11C.

2011. Deihim mansureae Ginter, Hairapetian and Klug; Ivanov and Lucas, p. 60, fig. 8.

2013. Deihim mansureae Ginter, Hairapetian and Klug; Habibi et al., p. 30, fig. 4.

MATERIAL: One tooth from the Virgin Hills Formation, Casey Falls, sample CL-471 and seven teeth from the Bugle Gap Limestone, samples 1984-96, 1984-97, 1984-98.

DESCRIPTION: Four morphotypes were originally assigned to the species Deihim mansureae Ginter et al. 2002, of which, two are represented here (Text-fig. CD). A single tooth attributed to morphotype one (Text-fig. $\mathrm{D}_{1-2}$ ) appears to possess a significantly worn central and lateral cusps with only the base of the crown preserved. The base of a large main central cusp can be distinguished, flanked by two smaller highly fused lateral cusps. Cristae is present on the base of the lateral cusps on the lingual face. The labial face of the crown possesses three large, robust cusplets (Text-fig. $6 \mathrm{D}_{2}$ ), immediately above the base. The crown-base interface on the lingual face is highly arched and defined by a shallow groove. The base is narrower, mesiodistally, than the crown and extends lingually with a series of deep canals.

Two teeth (Text-fig. $6 \mathrm{C}_{1-2}$ ), assigned to morphotype four were recovered and are characterised by an elongate central cusp and two well-spaced diverging lateral cusps approximately a third of the size of the medial cusp. Sub-parallel cristae are present on both the labial and lingual faces of each cusp. Four cusplets are present above the crown-base interface on the labial face. The base is roughly ovoid in outline (Textfig. $6 \mathrm{C}_{2}$ ) and does not extend beyond the crown mesiodistally. The lingual face of the base forms an arch, protruding lingually and is perforated by a few foramina.
REMARKS: The teeth described here conform to the diagnosis of $D$. mansureae with the presence of a prominent central cusp and lateral cusps that bear strong cristae, on a convex crown-base interface. A row of labial cusplets present above the crown base interface is also characteristic of this species. The teeth assigned to morphotype four resemble those of Ginter et al. (2010, pl. 5 D-F) with the presence of a slender central cusp with two lateral cusps, approximately half the size of the central cusp and diverging at 45 degree angles. These teeth also appear less perforated by foramina on the lingual face of the base and lack the fusing of the central and lateral cusps that is seen in the other morphotypes of this species.

DISTRIBUTION AND STRATIGRAPHIC RANGE: D. mansureae ranges from the Late marginifera $\mathrm{CZ}$ to possibly the Tournaisian in the Canning Basin. An older occurrence of this species is known from the rhenana (MN $11 \mathrm{CZ}$ ) in Kale Sardar area of Iran (Hairapetian and Ginter 2010). In the Famennian of Iran and Armenia D. mansureae ranges into the Upper crepida conodont Zone. Teeth attributed to this species have also been found in the Sly Gap Formation, New Mexico, USA (Ivanov and Lucas 2011), however no concise age range beyond the Late Devonian and Early Carboniferous can be ascertained.

Deihim cf. mansureae Ginter, Hairapetian and Klug, 2002 (Text-fig. 6E)

MATERIAL: Two teeth from the Bugle Gap Limestone, Casey Falls, sample 1984-98.

DESCRIPTION: Teeth with prominent central cusps and two smaller lateral cusps approximately one third the size of the medial cusp, diverging at approximate 45 degree angles (Text-fig. $6 \mathrm{E}_{1}$ ). Each cusp is rounded with sub parallel striations on both the labial and lingual faces. A row of seven rounded cusplets, ornamented in strong cristae are present on the base of the crown along the labial face (Text-fig. $6 \mathrm{E}_{2}$ ). The base is ovoid in outline, extending lingually and possessing a single small pore located centrally on the lingual rim. On the labial face the base is thin and forms an undulated contact with the crown.

REMARKS: These teeth are similar to the morphotype 1 of Deihim mansureae as they comprise a crown with a large central cusp with two strongly diverging lateral cusps, all ornamented in a strong cristae as well 
as a row of lingual cusplets along the labial face of the tooth. The cusplets present on the teeth described here are unusual but bear a strong resemblance to the cusplets on a tooth from $D$. mansureae in central Iran (Hairapetian and Ginter 2009, figs $5 \mathrm{H}_{2-3}$ ). Despite the similarities with $D$. mansureae, the tooth lacks both the arched lingual groove associated with the crown base interface as well as the series of deep pore canals on the lingual face diagnostic of this species (Ginter et al. 2002). These features are also lacking on a tooth attributed to Protacrodus cf. vetustus from the Montagne Noire (Ginter 2000, fig. 8C). The Montagne Noire tooth shares the similar sub-parallel cristae to the teeth from the Canning Basin, however it lacks labial cusplets.

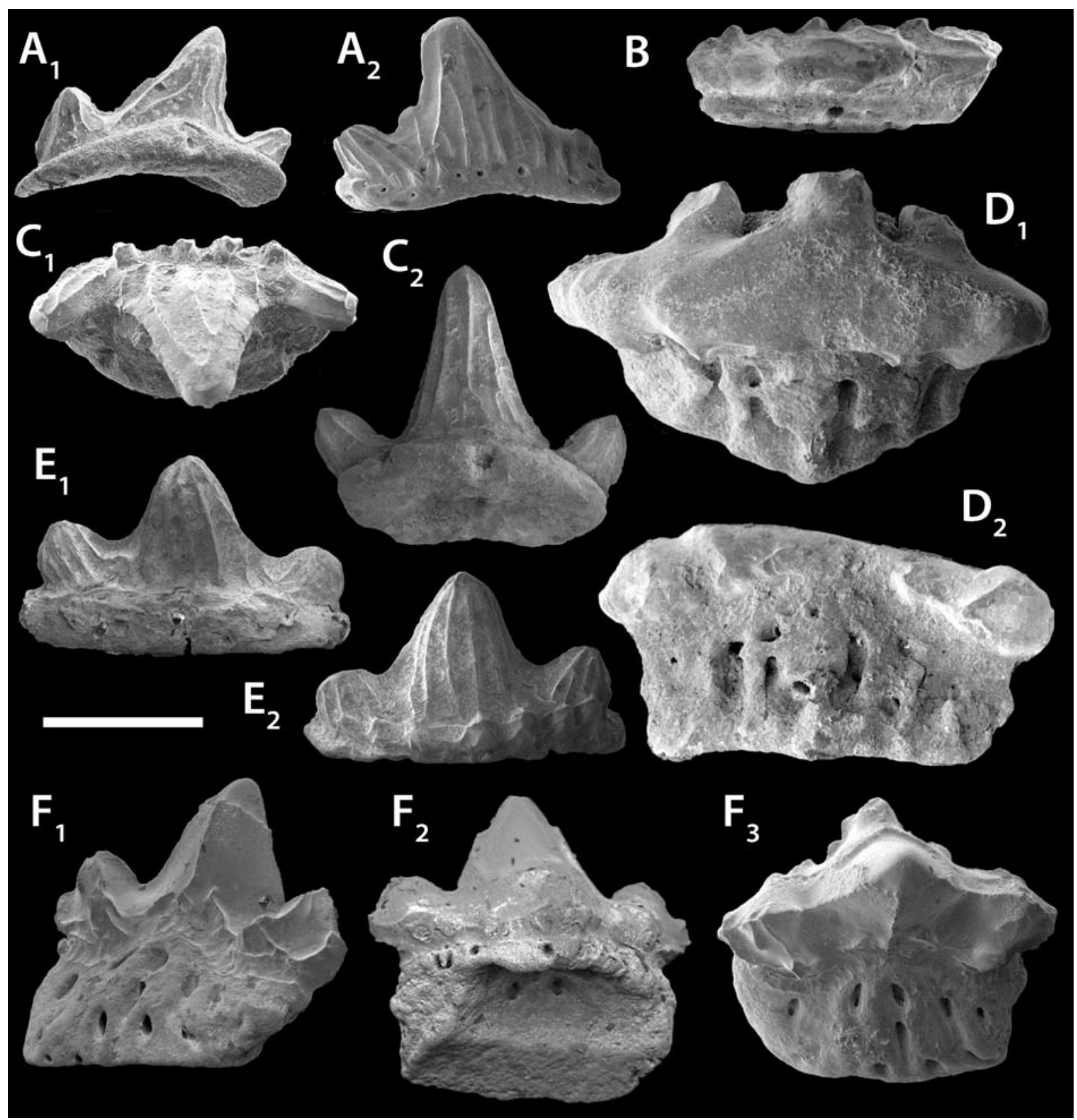

Text-fig. 6. Protacrodont teeth from Casey Falls. A-B - Protacrodus serra. A - WAM 14.7.21, sample 1984-97, in lingual and labial views; B - WAM 14.7.23, sample CL-471, in occlusal view; C-D - Deihim mansureae. C - WAM 14.7.25, sample 1984-98, in lingual and occlusal views; D - WAM 14.7.28, sample 1984-97, in lingual and occlusal views; E, Deihim cf. mansureae, WAM 14.7.24, sample 1984-98, in lingual and labial views; F, Deihim sp. 1, WAM 14.7.17, sample CL-471, in lingual, baso-labial and occlusal views. Scale bar $0.5 \mathrm{~mm}$ 
MATERIAL: One tooth from Bugle Gap Limestone, Casey Falls, sample CL-471.

DESCRIPTION: A well preserved, almost symmetrical tooth with a prominent central cusp and two pairs of highly fused lateral cusplets (Text-fig. $6 \mathrm{~F}_{1}$ ). Cusps are ornamented on the lingual face in strong cristae along the base of the cusps with a single ridge running up the centre of the central cusp. A crown-base interface is prominent, marked by a groove on both the lingual and labial faces of the tooth (Text-fig. $6 \mathrm{~F}_{1}$ ). A triangular labial peg is positioned at the base of the central cusp with accompanying smaller projections on either side (Text-fig. $6 \mathrm{~F}_{2-3}$ ). The base is approximately the same height as the central cusp with a straight lingual edge and rounded distal margins. A series of foramina are present on the lingual face of the base in almost two rows, one slightly below the crown base interface and another close to the lingual rim (Text-fig. $6 \mathrm{~F}_{1}$ ). A large articulation socket is present on the basolabial face of the base (Text-fig. $6 \mathrm{~F}_{2}$ ).

REMARKS: The tooth described here comprises a large central cusp with diverging cusps ornamented in strong cristae which are diagnostic of the genus Deihim (Ginter et al. 2002). Further similarities include the presence of a crown base interface separating a lingually extended base perforated by a series of canals. Despite the similarities, Deihim sp. 1 comprises a central cusp which is more prominent than that found on morphotype 1 of D. mansureae and it also lacks the characteristic labial cusplets. Instead the tooth from the Canning Basin bears small tubercle-like projections above the crown base interface on the extended labial face of the crown. The general morphology of Deihim sp. 1 also bears a slight resemblance to Protacrodus orientalis Li, 1988 with the high central cusp, fused laterals and a labial projection of the central cusp (Li 1988, pl. 1, fig. 2), however the size difference in the cusps excludes this tooth from $P$. orientalis (Ginter et al. 2002). There is also a very strong resemblance to another tooth attributed to $P$. orientalis from the Menggongao Formation, South China (Lelièvre and Derycke 1998, fig. 7B) which is narrower mesiodistally with the same cusp morphology and deep base. Recently, the inclusion of $P$. orientalis as a species of Protacrodus has been questioned (Ginter et al. 2010). It is possible that $P$. orientalis belongs to the genus Deihim and the tooth from the Canning Basin represents a less abraded form of this species.

Protacrodontidae gen. sp. indet. 1 (Text-fig. 7A)
MATERIAL: One tooth from the Bugle Gap Limestone, Casey Falls, sample 1984-94.

DESCRIPTION: Highly elongate and slightly arched tooth comprising a prominent pyramidal central cusp accompanied by four to five fused lateral cusps approximately a quarter of the size of the central cusp (Text-fig. 7A 1 ). Both the labial and lingual faces of the cusps are ornamented in coarse wavy cristae directed towards the cusp apices. Approximately $80 \%$ of the lingual face of the base is broken, however the preserved section is the same height as the lateral cusps and extends both lingually and further mesiodistally than the crown on one side (Text-fig. $7 \mathrm{~A}_{2}$ ). A small number of foramina are present on the lingual face of the base. The labial margin of the base is thin and perforated by small foramina and lacks a distinct crown base interface (Text-fig. 7 $\mathrm{A}_{2}$ ).

REMARKS: The tooth is placed under Protacrodontidae based on the coarse cristae and lack of articulation devices also found in other Devonian Protacrodonts as well as its occurrence within the middle Devonian. The tooth is also similar to a partial tooth of a ?Protacrodontid (Ginter and Sun 2007, fig. 4E) from Muhua, southern China in that it shares the highly elongate shape, with extensively fused lateral cusps flanking a prominent central cusp and a well-developed cristae. However, the tooth described here lacks the festoon-like sculpture on the lower aspect of the crown present on the Chinese tooth (Ginter and Sun 2007).

?Protacrodontidae fam. gen. sp. indet. (Text-fig. 7B)

MATERIAL: One tooth from the Bugle Gap Limestone, Casey Falls, sample CL-471.

DESCRIPTION: A mesio-distally elongate tooth with a crown consisting of highly fused cusps that are almost indistinguishable. Strong cristae are present on the labial and lingual faces as well as the occlusal surface (Text-fig. $7 \mathrm{~B}_{1-3}$ ). The labial face of the crown is higher and slopes lingually. The distal margins of the crown taper inward to the crown-base interface, whereas the labial and lingual faces are almost straight. The base is roughly rectangular in outline with a slightly thickened, protruding lingual margin. A row of pore canals are present along the lingual face of the base (Text-fig. $7 \mathrm{~B}_{2}$ ), where as possible remnants of canals are present on the labial face (Text-fig. 7B $\mathrm{B}_{3}$. 
REMARKS: Teeth with coarse cristae, a reduced base lacking both a lingual extension and articulation devices are common among Devonian protacrodonts. The crown of the tooth described here, retains more highly fused cusps than other protacrodont teeth and in this respect it more closely resembles an orodont. The reduced base and lack of distinct margin between the crown and base along the labial margin appear similar to the lingual face of the teeth attributed to P. serra and Protacrodus aequalis Ivanov 1996. The samples taken above the section measured at Casey Falls are dominated by protacrodontid-type teeth (Protacrodus serra, Deihim mansureae, D. cf. mansureae, Deihim sp. 1, Protacrodontidae gen. et sp. indet.; Table 1), which could suggest it belongs to the family Protacrodontidae and is highly modified, possibly representing a lateral crushing tooth.

Order Hybodontiformes Cappetta, Duffin and Zidek, 1993

Superfamily Hybodontoidea Owen, 1846

Family Lonchidiidae Herman, 1977

Genus Lissodus Brough, 1935

TYPE SPECIES: Hybodus africanus Bloom, 1909.

Lissodus lusavorichi Ginter, Hairapetian and Grigoryan, 2011

(Text-fig. 7C)

2011. Lissodus lusavorichi sp. nov. Ginter, Hairapetian and Grigoryan, p. 160, fig. 10E-F.
MATERIAL: Two teeth from the Virgin Hills Formation, Casey Falls, sample 1983-94.

DESCRIPTION: The tooth crown is broadly triangular with a well-developed occlusal crest (Textfig. $7 \mathrm{C}_{1}$ ). The crown extends laterally beyond the base terminating in triangular shoulders. The crown base interface is slightly arched on the lingual face and prominent on the labial face (Text-fig. $7 \mathrm{C}_{2}$ ). A well-developed labial peg is present and accompanied by small cusplets or tubercle like projections. The base is typically euselachian, projecting lingually with a rounded margin. A series of deep, elongated canals perforate the lingual face of the base (Text-fig. $7 \mathrm{C}_{1}$ ).

REMARKS: The teeth from Casey Falls are attributed to Lissodus lusavorichi Ginter et al. 2011, as they possess the same smooth broad triangular crown, well developed occlusal crest and horizontal longitudinal crown shoulders as well as the tubercles associated with the labial peg. The presence of this species represents the oldest record of the family Lonchiididae in the Canning Basin.

DISTRIBUTION AND STRATIGRAPHIC RANGE: The species has been previously described from the expansa zone in Dalmeh, Iran and probable expansa zone, Khor Virap Armenia. Its presence in the Upper marginifera conodont Zone in the Canning Basin, refines the lower age range of this species.

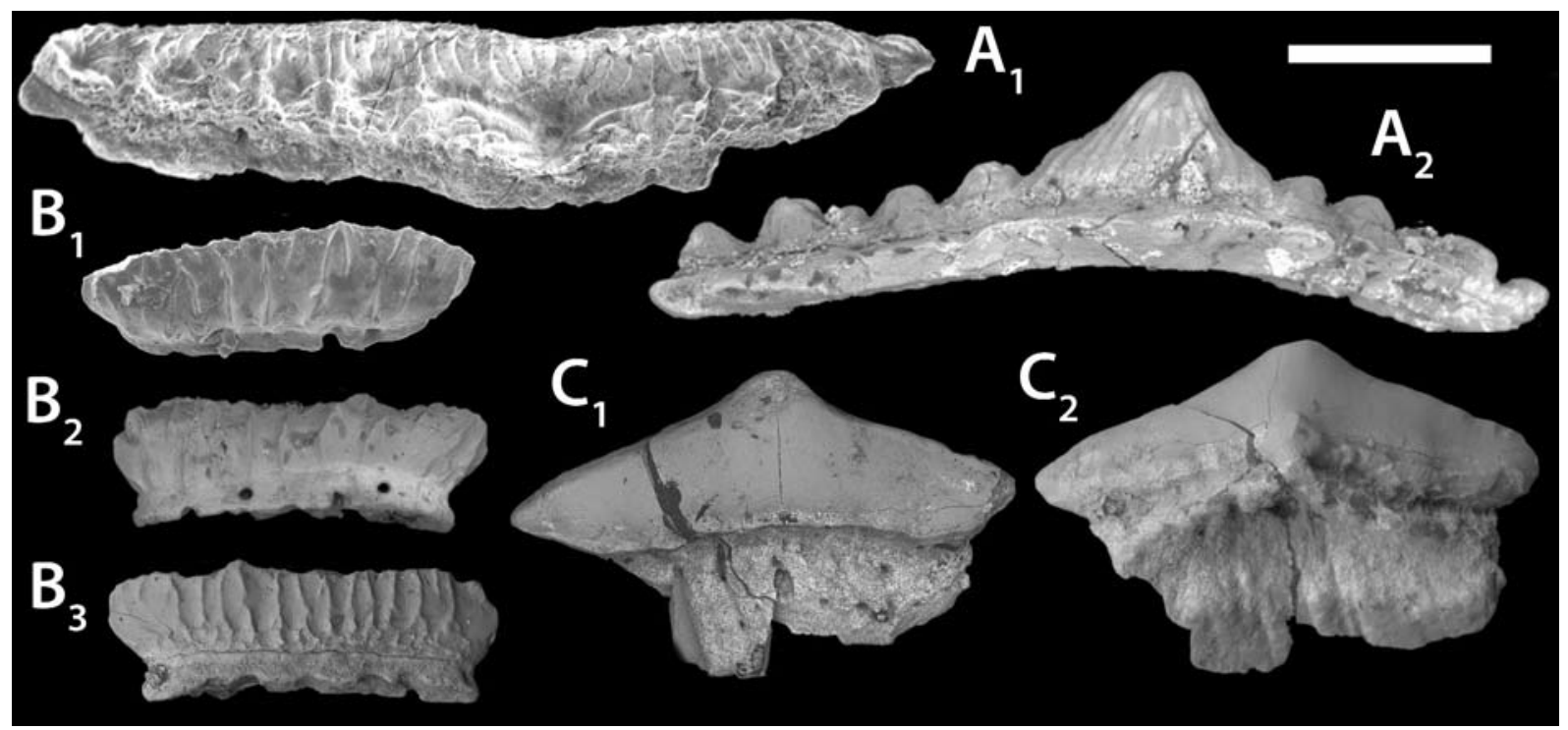

Text-fig. 7. Shark teeth from the Casey Falls. A - Protacrodontidae gen. et. sp. indet 1, WAM 14.7.22, sample 1984-94, in occlusal and labial views; B - ?Protacrodontidae gen. et sp. indet WAM 14.7.31, 1984-98, in occlusal, lingual and labial views; C - Lissodus lusavorichi, WAM 14.7.30, sample 1984-98, in labial and lingual views. Scale bar $0.5 \mathrm{~mm}$ 


\section{DISCUSSION}

\section{Biostratigraphy}

Thelodonts have been successfully used in biostratigraphy since the 1960's (Gross 1967) with current global zonation schemes (in Gradstein et al. 2012) developed for the Silurian (Turner 1973; Bassett et al. 1982; Märss et al. 1995; Blom 1999; Talimaa 2000) and Devonian, (Turner 1995a, 1999; Blom and Goujet 2002; Hairapetian et al., in press). Subsequent to the Givetian-Frasnian boundary, thelodonts are restricted to the margins of northern Gondwana (Turner 1997; Trinajstic 2001; Märss et al. 2007) and there is a marked reduction in diversity with the Turinidae Family represented by the species Australolepis seddoni (Seddon 1969; Turner and Dring 1981; Trinajstic and George 2009), Turinia hutkensis (Blieck and Goujet 1978; Hairapetian et al. 2006) and a new genus and species of turiniid (Hairapetian et al., in press). Of these, A. seddoni has been particularly useful in defining shallow water Frasnian strata in northern Gondwana (Turner et al. 2002). The species is known from the falsiovalis to rhenana conodont Zones (MN 1-10 CZ) in Iran and provided a lower Frasnian age constraint for the Chariseh section (Turner et al. 2002). Within Australia this species is now recognised as ranging from MN 6-11 CZ and has been previously used to constrain a Frasnian age for the base of the Gneudna Formation type section in the Carnarvon Basin (Turner and Dring 1981; Trinajstic and George 2009). Within the Canning Basin A. seddoni has been used to confirm a Frasnian age for the Hull platform (Chow et al. 2013). Although the increased range of A. seddoni, decreases the ability to obtain more finely resolved ages for strata, its confinement to the Frasnian still makes this species an important zone fossil.

The phoebodont taxa recovered in this study conform to previously established age ranges obtained for these species in the Canning Basin (Trinajstic and George 2009) with the exception of Phoebodus latus where the range has been extended from $\mathrm{MN} 10 \mathrm{CZ}$ to MN $11 \mathrm{CZ}$. This newly extended range of $P h$. latus in the Canning Basin brings it closer in line with the known upper age range for this species (MN $13 \mathrm{CZ}$ ) in the Southern Urals and South Timan in Russia as well as the Holy Cross Mountains in Poland (Ginter and Ivanov 1995b; Ivanov 1999; Ivanov and Lucas 2011). The extension of the known age ranges for $A$. seddoni and Ph. latus in the Canning Basin indicates further refinement of the age ranges for other phoebodont taxa such as Ph. bifurcatus and Ph. fastigatus is likely with further collecting. Work so far undertaken describing the phoebodont fauna from the Canning Basin (Trinajstic and George 2009), has proven their utility in biostratigraphy as well as increasing the geographic distribution in which these species can be used.

A disappearance in phoebodont fauna is seen in the section at Horse Spring from MN $11 \mathrm{CZ}$ and occurs too early to be attributed to the global Kellwasser Events. Despite the distinct anoxic black limestones and shales associated with the Kellwasser horizons not being recognised in the Canning Basin (Becker et al. 1993), perturbations are recorded in the faunas. Reductions in the species diversity and abundances are recorded within conodonts (Klapper 2007), ammonoids (Becker et al. 1993) and trilobites (Feist and McNamara 2013) in the Canning Basin which are also seen in the rest of the world. The absence of microvertebrates at Horse Spring above MN CZ 11 was previously noted by Trinajstic and George (2009) who suggested post depositional dolomitisation as the main factor contributing to the lack of microvertebrates. However, this does not seem to be the cause as microvertebrates are often recovered from dolomitised beds. In addition, conodonts were found in the dolomitised beds from 13-19 m (Text-fig. 2) in the section at Horse Spring where microvertebrate fossils were lacking. A global non-occurrence of the Phoebodus bifurcatus group from the linguiformis Zone (MN 13b CZ) in the Frasnian to the Famennian late crepida conodont Zone has been identified in the Northern Hemisphere (Ginter and Ivanov 1995b; Ginter et al. 2002). Ginter et al. (2002) suggests the disappearance mainly resulted from global cooling (Copper 1998) rather than fluctuations in sea level or anoxia. Given the much earlier disappearance of phoebodonts in the section at Horse Spring, and no evidence of major temperature excursions in sea surface temperatures during the MN $11 \mathrm{CZ}$ (Joachimski et al. 2004), it is not likely temperature fluctuations are the reason for the disappearance of a phoebodont non-occurrence at Horse Spring.

Another notable global change recorded towards the end of the Frasnian is the semichatovae Transgression (Sandberg et al. 1997). This event occurs at the base of the MN 11 Zone and coincides with the absence of phoebodont taxa in the Canning Basin. Despite reported localised tectonic overprinting (Southgate et al. 1993; George and Chow 2002; Chow et al. 2013), evidence of a longer-term $2^{\text {nd }}$ order transgressive event is observable in these sections. The effect of these localised and global events may be highly influential in the faunal changes and extinctions seen in the basin (George and Chow 2002). The phoebodont group has been previously noted as niche sensitive (Ginter 
and Turner 1999), which may explain their apparent confinement to specific sites in the Canning Basin. Following any ecological disturbance within the Horse Spring area, a migration of phoebodont taxa may have occurred. In this scenario, the disappearance in MN 11 $\mathrm{CZ}$ would reflect a movement of these sharks rather than the extinction seen in other areas of the world, such as Poland at the linguiformis CZ (13b) (Ginter et al. 2002). It is important to note that a re-emergence of the phoebodont group in the Famennian is present along both the North and Eastern margins of Gondwana as well as Laurussia (Ginter and Turner 1999; Ginter and Ivanov 2000; Ginter et al. 2002). Interestingly, this re-emergence is not reflected in the studied sections here and could indicate the factor or factors influencing the non-occurrence of phoebodonts in the Canning Basin were potentially long lasting and perhaps localised. A collecting bias can also not be ignored as there have only been limited studies in the Canning Basin focusing on Frasnian microvertebrate faunas.

The current phoebodont based zonation established for the Famennian (Ginter and Ivanov 1995b; Gradstein et al. 2012) has not yet been correlated in the Canning Basin and this is partly due to the study of Famennian vertebrates being in its infancy. The sections described also do not encompass the open shelf environment where this scheme is most applicable (Ginter et al. 2002) and may account for the lack of Phoebodus teeth in the Famennian dated intervals. Despite a lack of Phoebodus species in the Bugle Gap Limestone, the recovered shark species exhibit comparable ages for the same species found in other areas of the world. Of these, Thrinacodus tranquillus has been recorded as occurring from the Middle to Late Devonian in Laurussia and North Gondwana (Ginter and Turner 2010). The presence of this species in the Canning Basin makes it one of the oldest global occurrences (Upper marginfera $\mathrm{CZ}$ ) with similar ages recorded in Morocco, South China and Iran (Lelièvre and Derycke 1998; Hairapetian and Long 2000; Ginter et al. 2002). The oldest report of the protacrodont Deihim mansureae is from the Late Frasnian, rhenana (MN 11 CZ) in Kale Sardar area of Iran (Hairapetian and Ginter 2010). This species is far more wide spread in the Famennian, extending from the east of Laurussia (Ivanov and Lucas 2011) to the north-west of Gondwana. An Upper crepida conodont Zone is recorded as the upper range of $D$. mansureae in both Iran and Armenia. In the Canning Basin, Australia the range extends further, from Upper marginifera $\mathrm{CZ}$, into the lower Tournaisian (Burrow et al. 2010). Two other shallow water shark species, Protacrodus serra and Lissodus lusavorichi, been recorded from the expansa $\mathrm{CZ}$ of the Khor Virap region in Armenia and Dalmeh in Iran (Ginter et al. 2011). The presence of both P. serra and L. lusavorichi in the Canning Basin extends the lower age range of these species from the expansa conodont Zone to Upper marginifera. Like $D$. mansureae, an increased Famennian distribution of Th. tranquillus, L. lusavorichi and P. serra in Northern Gondwana is established. The presence of small, shallow water genera such as Deihim, Lissodus and Protacrodus across the margins of North Gondwana, would support the presence of a continuous shallow platform and reef environmental (Golonka 2007) suitable for faunal exchange.

\section{Biogeography and chondrichthyan assemblages}

Chondrichthyan biofacies present in the depauperate Famennian intervals of the Virgin Hills and Napier formations are often difficult to determine. These intervals often comprise largely shallow water and slope derived material. This results in the microvertebrate remains often not representing an original environment of habitation. In contrast to the described sections, samples taken from the shallow fore-reef deposits of the Bugle Gap Limestone (Guppy et al. 1958; Playford and Lowry 1966; Playford et al. 2009) preserve a more original chondrichthyan biofacies. A diverse shark genera including Thrinacodus, Stethacanthus, Protacrodus, Deihim and Lissodus were present in these shallow water facies. Despite the low numbers of teeth recovered from the Bugle Gap Limestone, the proportionally higher number of protacrodont and hybodont type sharks as well as the absence of Phoebodus and Jalo$d u s$, is indicative of a shallow water Protacrodus biofacies (Ginter 2000, 2001). Similar assemblages have also been recorded in Famennian strata from both Dalmeh and Chahriseh, Iran (Ginter et al. 2002; Hairapetian and Ginter 2010).

An increase in cosmopolitanism is seen in many Late Devonian marine groups, including brachiopods (Copper 1998), ammonoids (House 1973), trilobites (McNamara and Feist 2006), crustaceans (Rode and Lieberman 2005), conodonts (Girard et al. 2010) and fish (Ginter and Turner 1999; Burrow et al. 2010). This faunal exchange between areas was likely driven by the closure of the Rheic Ocean (Nance et al. 2012; Domeier and Torsvik 2014) during the Late Devonian, culminating in an increased proximity of Laurussia and Gondwana (Young 2003; Burrow et al. 2010; Young et al. 2010). This period also saw the rifting of the Palaeotethys resulting in a separation of the north 
China, Indochina, Tarim and South China blocks from Gondwana (Metcalfe 1984, 2011). Connections between South China and north-west Australia were maintained in the Late Devonian by the occurrence of an extensive, shallow water shelf (Golonka 2007; Metcalfe 2011; Golonka and Gaweda 2012). Previous work on Late Devonian conodonts (Burrett et al. 1990; Girard et al. 2010) and fish (Long 1993) support a close relationship between the two areas. In addition, Trinajstic and George (2009) had previously shown close affinities, in regards to the temporal ranges, of the Frasnian phoebodonts $P$. fastigatus and Ph. bifurcatus in the Canning Basin and South China. The presence of a likely shallow water taxon, Deihim sp.1 (Text-fig. $6 \mathrm{G}_{1-3}$ ) in both the Canning Basin and Menggongao Formation of South China (Lelièvre and Derycke 1998, fig. 7B), would support the presence of a shallow water platform between the two areas into the middle part of the Famennian. Determining the extent of faunal exchange further into the Famennian or even Carboniferous is difficult, as studies into shark faunas of these ages are limited for the north west of Australia. However Th. ferox has been reported in the late Famennian in both South China and Australia (Long and Burrett 1989). The similarities between the tooth identified here as Protacrodontidae sp. 1 (Textfig. $7 \mathrm{~A}_{1-2}$ ) found in a middle Famennian of the Virgin Hills Formation and a tooth from the middle Tournaisian in Muhua, South China (Ginter and Sun 2007, fig. $E_{1-2}$ ) provides further support for a close connection between China and Australia (Metcalfe 2001) however, further data from microvertebrates are required.

Clear links between the shark taxa in the north-west of Australia and other parts of Laurussia, South China and Northern areas of Gondwana are demonstrated here. Despite the similarities, there is also a degree of endemism amongst some of the shark species present in the Canning Basin. This is not unusual as endemism in some conodont (Klapper 1995, 2007) and many placoderm (Long 2006) species has also been noted. Of the Frasnian taxa Diademodus dominicus sp. nov. had not been previously recorded outside of Laurussia. The presence of this species along the eastern margins of North Gondwana would also suggest a greater distribution of this genus than previously recognised. Of the other phoebodontids, Phoebodus tooth forms found in the Horse Spring section often possess unusual features. These include the tricuspid form of Ph. bifurcatus which appear relatively common in the Canning Basin but rare in other areas of the world. The teeth of $P h$. fastigatus also differ from the diagnostic smooth cusps, often possessing cusps with heavy ornament on the labial face. In addition to the Frasnian taxa, there are two types of ctenacanthiform and a species of Stethacanthus that have not been found anywhere else. Despite an increased cosmopolitanism in Devonian shark faunas, a considerable endemic component is present in the Canning Basin. The mechanisms for this are difficult to determine and may be the result of lack of sampling, although unique palaeoenvironmental conditions or environmental niches might have existed in this part of East Gondwana (north-western Australia) at this time.

\section{CONCLUSIONS}

A largely undescribed chondrichthyan fauna ranging in age from MN $11 \mathrm{CZ}$ in the late Frasnian to the late marginifera Zone in the middle Famennian was recorded from the Virgin Hills Formation, and the $\mathrm{Bu}-$ gle Gap Limestone, and Napier Formation in the Canning Basin. The section at Horse Springs reveals a similar diversity of phoebodonts to that previously described by Trinajstic and George (2009). A new species of diademodont, Diademodus dominicus sp. nov., a genus which until now had only previously been described from Laurussia was recovered from the phoebodont-rich beds. This species, in addition to variation in Phoebodus fastigatus, as well as newly described cladodont and stethacanthid teeth, reveals a potentially endemic Frasnian component to the Canning Basin.

The Famennian Bugle Gap limestone and uppermost beds of the section at Casey Falls reveals a diverse shark fauna that had not been previously described from the Canning Basin. Many of these, including Th. tranquillus, C. wildungensis, P. serra, D. mansureae and L. lusavorichi, represent ages similar to or the same as those previously described for these species. The presence of this shark fauna in the Canning Basin also allows for a more comprehensive understanding of species distribution in the Famennian. A number of genera including Phoebodus and Protocrodus occur in both eastern Australia and Western Australia (Turner and Young 2000), however, these new reports on chondrichthyans from the Canning Basin indicate stronger faunal links between the Canning Basin and other areas of Gondwana such as Iran and Morocco as well as Poland and the United States of America in Laurussia. In addition, faunal similarities between South China and the Canning Basin are present, with some shark species indicating potential faunal exchange extending into the Late Famennian and possible Early Carboniferous. 


\section{Acknowledgements}

We would like to thank Prof. Michal Ginter, Dr. Vachik Hairapetian, and Prof. Sue Turner for their helpful comments and assistance in the preparation of this work. Thank you to Dr. Arthur Mory, Mr. Roger Hocking and Dr. Peter Haines, from the Geological survey of Western Australia, for their assistance in fieldwork. The authors acknowledge the use of equipment, scientific and technical assistance of the Curtin University Electron Microscope Facility, which has been partially funded by the University, State and Commonwealth Governments. A thank you to Dr. Mikael Siversson from the Western Australian Museum for the use of the facilities. We would also like to acknowledge Australian Research Council (LP0883812), MERIWA, WAERA, CSIRO, Arc Energy, Chevron Australia Business Unit, Chevron Energy Technology Company, University of Greenwich, National Science Foundation and Chemostrat Inc. Field support and safety provided by Wundargoodie Aboriginal Safaris and the Geological Survey of Western Australia. Thank you to Mimbi Community, Mt. Pierre Station, Fossil Downs, for field area access. BR also acknowledges an Australian Postgraduate Award.

\section{REFERENCES}

Aboussalam, Z.S. 2003. Das "Taghanic-Event" im höheren Mittlel-Devon von West-Europa und Marokko. Münstersche Forschungen zur Geologie und Paläontologie, 97, 1330 .

Agassiz, J.L.R. 1833-44. Recherches sur les poissons fossils, 5 vols. 1420 pp. with supplements. Petitpierre, Neuchâtel et Soleure.

Basden, A., Burrow, C.J., Hocking, M., Parkes, R. and Young, G.C. 2000. Siluro-Devonian microvertebrates from south-eastern Australia. In: Blieck, A., Turner, S. (Eds), Palaeozoic Vertebrate Biochronology and Global Marine/Non-Marine Correlation. Final Report of IGCP 328 (1991-1996). Courier Forschungsinstitut Senckenberg, 223, 201-222.

Bassett, M.G., Lawson, J.D. and White, D.E. 1982. The Downton Series as the fourth series of the Silurian System. Lethaia, 15, 1-24.

Bass, A.J., D’Aubrey, J.D. and Kistnasamy, N. 1973. Sharks of the east coast of Southern. Africa. I. The genus Carcharinus (Carcharhinidae). Investigational Report Oceanographic Research Institute, 33, 1-168.

Becker, M.A., Chamberlain, J.A. and Stoffer, P.W. 2000. Pathological tooth deformities in modern and late Cretaceous chondrichthyans: A consequence of feeding related injury. Lethaia, 36, 1-16.

Becker, R.T. 2000. Ammonoidea. In: Wright, A.J., Young, G.C., Talent, J.A. and Laurie, J.R. (Eds), Paleobiogeography of Australasian faunas and floras. Association of
Australasian Paleontologists, Memoir, 23, 177-180.

Becker, R.T., House, M.R. and Kirchgasser, W.T. 1993. Devonian goniatite biostratigraphy and timing of facies movements in the Frasnian of the Canning Basin, Western Australia. Geological Society, London, Special Publications, 70, 293-321.

Blieck, A. and Goujet, D. 1978. A propos de nouveau matériel de thelodontes (vertébrés agnathes) d'Iran et de Thaïlande: aperçu sur la répartition géographique et stratigraphique des agnathes des regions gondwaniennes au Paléozoïque moyen. Annales de la Societe Géologique du Nord, 97, 363-373.

Blom, H. 1999. Loganellia (Thelodonti, Agnatha) from the Lower Silurian of North Greenland. Acta Geologica Polonica, 49, 97-104.

Blom, H. and Goujet, D. 2002. Thelodont scales from the Lower Devonian Red Bay Group, Spitsbergen. Palaeontology, 45, 795-820.

Bonaparte, C.L.J.L. 1838. Selachorum tabula analytica. Nuovi Annali delle Scienze Naturali, 1, 195-214.

Brough, J. 1935. On the structure and relationships of the hybodont sharks. Memoirs and Proceedings of the Manchester Literary and Philosophical Society, 79, 35-49.

Burrett, C.F., Long, J. A. and Stait, B. 1990. Early-Middle Palaeozoic biogeography of Asian Terranes derived from Gondwana. Memoirs of the Geological Society of London, 12, 163-174.

Burrow, C. 1996. Taphonomy of acanthodians from the Devonian Bunga Beds (Late Givetian/Early Frasnian) of New South Wales. Boucot Festschrift. Historical Biology, 11, 213-228.

Burrow, C.J. 1997. Microvertebrate assemblages from the Lower Devonian (pesavis/sulcatus zones) of central New South Wales, Australia. Modern Geology, 21, 43-77.

Burrow, C.J. and Simpson, A.G. 1995. A new ischnacanthid acanthodian from the Late Silurian (Ludlow, ploeckensis zone) Jack Formation, north Queensland. Memoirs of the Queensland Museum, 38, 383-395.

Burrow, C.J. and Turner, S. 1998. Devonian placoderm scales from Australia. Journal of Vertebrate Paleontology, 18, 677-695.

Burrow, C.J. and Turner, S. 2000. Silurian vertebrates from Australia. In: Blieck, A., Turner, S. (Eds), Palaeozoic Verte brate Biochronology and Global Marine/Non-Marine Correlation. Final Report of IGCP 328 (1991-1996). Courier Forschungsinstitut Senckenberg, 223, 169-174.

Burrow, C.J., Turner, S. and Young, G.C. 2010. Middle Palaeozoic microvertebrate assemblages and biogeography of East Gondwana (Australasia, Antarctica). Palaeoworld, 19, 37-54.

Cappetta, H., Duffin, C.J. and Zidek, J. 1993. Chondrichthyes. In: M.J. Benton (Eds), The Fossil Record 2: 593-609. Chapman and Hall; London. 
Chow, N., George, A.D., Trinajstic, K.M. and Chen, Z. 2013. Stratal architecture and platform evolution of an early Frasnian syn-tectonic carbonate platform, Canning Basin, Australia. Sedimentology, 38, 1-38.

Copper, P. 1998. Evaluating the Frasnian-Famennian mass extinction: Comparing brachiopod faunas. Acta Palaeontologica Polonica, 43, 137-154.

Dean, B. 1909. Studies on fossil fishes (sharks, chimaeroids and arthrodires). American Museum of Natural History Memoir, 9, 211-287.

Derycke, C. 1992. Microrestes de sélaciens et autres Vertebres du Dévonien supérieur du Maroc. Bulletin de Muséum national d'Histoire naturelle, 14, 15-61.

Derycke-Khatir, C. 2005. Microrestes de Vertébrés du Paléozoïque supérieur de la Manche au Rhin. Société géologique du Nord, 33, 261.

Derycke, C,, Spalletta, C,. Perri., M.C. and Corradini, C. 2008. Famennian chondrichthyan microremains from Morocco and Sardinia. Journal of Palaeontology, 82, 984 995.

Domeier, M. and Torsvik, T.H. 2014. Plate tectonics in the late Paleozoic. Geoscience Frontiers, 5, 303-350.

Drummond, B.J., Sexton, M.J., Barton, T.J. and Shaw, R. D., 1991. The nature of faulting along the margins of the Fitzroy Trough, Canning Basin and implications for the tectonic development of the trough. Exploration Geophysics, 22, 111-116.

Duncan, M. 2003. Early Carboniferous chondrichthyan Thrinacodus from Ireland, and a reconstruction of jaw apparatus. Acta Palaeontologica Polonica, 48, 113-122.

Duffin, C.J. and Ginter, M. 2006. Comments on the selachian genus Cladodus Agassiz 1843. Journal of Vertebrate Paleontology, 26, 253-266.

Edwards, A.F. 1997. Ichthyolith remains from the DevonianCarboniferous Boundary of the Canning Basin, Western Australia. M.Sc, Thesis (unpublished). School of Earth Sciences, Macquarie University, Sydney.

Feist, R., and McNamara, K. J. 2013. Patterns of evolution and extinction in proetid trilobites during the late Devonian mass extinction event, Canning Basin, Western Australia. Palaeontology, 56, 229-259.

George, A.D. 1999. Deep-water stromatolites, Canning Basin, northwestern Australia. Palaios, 14, 493-505.

George, A.D. and Chow, N. 2002. The depositional record of the Frasnian/Famennian boundary interval in a fore-reef succession, Canning Basin, Western Australia. Palaeogeography, Palaeoclimatology, Palaeoecology, 181, 347374.

Ginter, M. 1990. Late Famennian shark teeth from the Holy Cross Mts, Central Poland. Acta Geologica Polonica, 40, 69-81.

Ginter, M. 1991. Ichthyoliths and fish-fauna. In: J. Hladil, Z. Krejci, J. Kalvoda, M. Ginter, A. Galle, and P. Berousek.
Carbonate ramp environment and biostratigraphy of Kellwasser time-interval (Lesni Lom, Moravia, Czechoslovakia), 75-77. Bulletin de la Société Belge de Géologie, 100, 57-119.

Ginter, M. 1995. Ichthyoliths and Late Devonian events in Poland and Germany. In: S. Turner (Ed.), Ichthyolith Issues, Special Publication, 1, 23-30.

Ginter, M. 2000. Late Famennian pelagic shark assemblages. Acta Geologica Polonica, 50, 369-386.

Ginter, M. 2001. Chondrichthyan biofacies in the Late Famennian of Utah and Nevada. Journal of Vertebrate $\mathrm{Pa}$ leontology, 21, 714-729.

Ginter, M. 2002. Chondrichthyan fauna of the Frasnian-Famennian boundary beds in Poland. Acta Palaeontologica Polonica, 47, 329-338.

Ginter M. 2004. Devonian sharks and the origin of Xenacanthiformes. In: Arratia G., Wilson M.V.H. and Cloutier R. (Eds), Recent Advances in the Origin and Early Radiation of Vertebrates, 473-486. Verlag Friedrich Pfeil; München.

Ginter, M. 2008. Devonian filter feeding sharks. Acta Geologica Polonica, 58, 147-153.

Ginter, M. and Ivanov, A. 1992. Devonian phoebodont shark teeth. Acta Palaeontologica Polonica, 37, 55-75.

Ginter, M. and Ivanov, A. 1995a. Middle/Late Devonian phoebodont-based ichthyolith zonation. Geobios, Memoire Special, 19, 351-355.

Ginter, M. and Ivanov, A. 1995b. New Late Devonian species of Phoebodus. In: Turner, S. (Ed.), Ichthyolith Issues Special Publication, 1, 19-22.

Ginter, M. and Ivanov, A. 1996. Relationships of Phoebodus. Modern Geology, 20, 263-274.

Ginter, M. and Ivanov, A. 2000. Stratigraphic distribution of chondrichthyans in the Devonian on the East European Platform margin. In: Blieck, A. and Turner, S. (Eds), Palaeozoic Vertebrate Biochronology and Global Marine/Non-Marine Correlation. Final Report of IGCP 328 (1991-1996). Courier Forschungsinstitut Senckenberg, 223, 325-339.

Ginter, M. and Sun, Y. 2007. Chondrichthyan remains from the Lower Carboniferous of Muhua, southern China. Acta Palaeontologica Polonica, 52, 705-727.

Ginter, M. and Turner, S. 1999. The early Famennian recovery of phoebodont sharks. Acta Geologica Polonica, 49, 105-117.

Ginter, M. and Turner, S. 2010. The Middle Paleozoic selachian genus Thrinacodus. Journal of Vertebrate Paleontology, 30, 1666-1672.

Ginter, M., Hampe, O. and Duffin, C. J. 2010. Chondrichthyes. Paleozoic Elasmobranchii: Teeth. In: H.-P. Schultze (Ed.), Handbook of Paleoichthyology 3D, pp. 1-168. Verlag Dr. Friedrich Pfeil, München.

Ginter, M., Hairapetian, V. and Grigoryan, A. 2011. Chondrichthyan microfossils from the Famennian and Tour- 
naisian of Armenia. Acta Geologica Polonica, 61, 153173.

Ginter, M., Hairapetian, V. and Klug, C. 2002. Famennian chondrichthyans from the shelves of North Gondwana. Acta Geologica Polonica, 52, 169-215.

Ginter, M., Liao, J.C. and Valenzuela-Rios, J.I. 2008. New data on chondrichthyan microremains from the Givetian of the Renanue section in the Aragonian Pyrenees (Spain). Acta Geologica Polonica, 58, 165-172.

Girard, C., Klapper, G. and Feist, R. 2005. Subdivision of the terminal Frasnian linguiformis conodont Zone, revision of the correlative interval of the Montagne Noire Zone 13, and discussion of the stratigraphically significant associated trilobites. In: Over, D.J., Morrow, J.R. and Wignall, P.B. (Eds), Understanding Late Devonian and PermianTriassic biotic and climatic events: towards an integrated approach: Towards an Integrated Approach. Developments in Paleontology and Stratigraphy Series, 20, 181198. Elsevier, Amsterdam.

Girard, C., Phuong, T.H., Savage, N. and Renaud, S. 2010. Temporal dynamics of the geographic differentiation of Late Devonian Palmatolepis assemblages in the Prototethys. Acta Palaeontologica Polonica, 55, 675-687.

Glenister, B.F. and Klapper, G. 1966. Upper Devonian conodonts from the Canning Basin, Western Australia. Journal of Palaeontology, 40, 777-842.

Glikman, L.S. 1964. Subclass Elasmobranchii. Sharks. In: Obručev, D.V. (Ed.), Osnovy paleontologii. Besčelustnye, ryby: 196-237. Nauka; Moskva.

Golonka, J. 2007. Phanerozoic Paleoenvironment and Paleolithofacies Maps. Late Paleozoic. Geologia, 33, 145-209.

Golonka, J. and Gaweda, A. 2012. Plate tectonic evolution of the southern margin of Laurussia in the Paleozoic. In: Sharkov, E. (Ed.), Tectonics recent advances. InTech, 261-282.

Gradstein, F.M., Ogg, J.G., Schmitz, M. and Ogg, G. (Eds). 2012. The geological timescale 2012. Elsevier, Oxford.

Gross, W. 1967. Über Thelodontiers Schuppen. Palaeontographica Abteilung A, 127, 1-67.

Gross, W. 1973. Kleinschuppen, Flossenstacheln und Zähne von Fischen aus europäischen und nordamerikanischen Bonebeds des Devons. Palaeontographica A, 142, 51155.

Guppy, D.J., Lindner, A.W., Rattigan, J.H. and Casey, J.N. 1958, The geology of the Fitzroy Basin, Western Australia: Australia. Bureau of Mineral Resources Bulletin, 36, 1116.

Habibi, T, Yazdi, M., Zarepoor, S. and Shirazi, M.P. 2013. Late Devonian fish micro-remains from Central Iran. Geopersia, 3, 25-34.

Hairapetian, V. and Ginter, M. 2009. Famennian chondrichthyan remains from the Chahriseh section, central Iran. Acta Geologica Polonica, 59, 173-200.
Hairapetian, V. and Ginter, M. 2010. Pelagic chondrichthyan microremains from the Upper Devonian of the Kale Sardar section, eastern Iran. Acta Geologica Polonica, 60, 357-371.

Hairapetian, V., Yazdi, M. and Long, J.A. 2000. Devonian vertebrate biostratigraphy of central Iran. Records of the Western Australian Museum, Supplement, 58, 241-247.

Hairapetian, V., Valiukevičius, J. and Burrow, C. 2006. Early Frasnian acanthodians from Central Iran. Acta Palaeontologica Polonica, 51, 499-520.

Hairaptetian, V., Roelofs, B., Trinajstic, K. and Turner, S. (in press). Famennian survivor turiniid thelodonts of North and East Gondwana. In: Koenigshoef, P. \& Becker, T. (Eds). Devonian Climate, Sea-Level and Evolutionary Events. Geological Geological Society Special Publication.

Hampe, O., Aboussalam, Z.S. and Becker, R.T. 2004. Omalodus teeth (Elasmobranchii: Omalodontida) from the northern Gondwana margin (middle Givetian: ansatus conodont Zone, Morocco). In: G. Arratia, M.V.H. Wilson et al., (Eds), Recent advances in the origin and early radiation of vertebrates, 473-486. Friedrich Pfeil; München.

Harris, J.E. 1951. Diademodus hydei, a new fossil shark from the Cleveland Shale. Proceedings of the Zoological Society of London, 120, 683-697.

Hay, O.P. 1902. Bibliography and catalogue of the fossil Vertebrata of North America. Bulletin, United States Geological Survey, 179, 1-868.

Herman, J. 1977. Les sélaciens des terrains néocrétacés et paléocènes de Belgique et des contrées limitrophes: Eléments d'une biostratigraphie intercontinentale. Mémoirs pour servir à l'éxplication des Cartes géologiques et minières de la Belgique, 15, 1-450.

House, M. 1973. An analysis of Devonian goniatite distributions. Palaeontology Special Papers, 12, 305-317.

Huxley, T.H. 1880. On the application of the laws of evolution to the arrangement of the Vertebrata, and more particularly of the Mammalia. Proceedings of the Zoological Society, London, 43, 649-662.

Ivanov, A. 1992. Vertebrate fauna at the Frasnian/Famennian boundary of the South Urals. The International Symposium on Devonian System and Its Economic Oil and Mineral Resources, 9-12.09.92, Guilin, China. Abstract.

Ivanov, A. 1996. The Early Carboniferous chondrichthyans of the South Urals, Russia. In: Strogen, P., Somerville, I.D. and Jones, G.L. (Eds), Recent Advances in Lower Carboniferous Geology. Geological Society, Special Publication, 107, 417-425.

Ivanov, A. 1999. Late Devonian - Early Permian chondricthyans of the Russian Arctic. Acta Geologica Polonica, 49, $267-285$.

Ivanov, A.O. and Lucas, S.G. 2011. Paleozoic Sly Gap For- 
mation of southern New Mexico, USA. New Mexico Museum of Natural History and Science Bulletin, 53, 52-70.

Ivanov, A., Vûškova, L.], and Esin, D. 1992. Ichthyofauna. In: V. Krasnov and M. Ržonsnickaâ (Eds), Tipovye razrezy pograničnyh otloženij srednego i verhnego devona, franskogo ifamenskogo ârusov okrain Kuzneckogo bassejna. Materialy V vyezdnojsessii komisii MSK po devonskoj sisteme, Kuzbass, 16-29 iûlâ 1991 g., 89-91.

Jaekel, O. 1911. Die Wirbeltiere. Eine Übersicht über die fossilen und lebenden Formen. Borntraeger, Berlin.

Jaekel, O. 1921. Die Stellung der Paläontologie zur einigen Problemen der Biologie und Phylogenie. Schadelprobleme. Paläontologische Zeitschrift, 3, 213-239.

Jaekel, O. 1925. Das Mundskelett der Wirbeltiere. Gegenbaurs Morphologishes Jahrbuch, 55, 402-409.

Jeppsson, L., Anehus, R, and Fredhold, D. 1999. The Optimal Acetate Buffered Acetic Acid Technique for Extracting Phosphatic Fossils. Journal of Paleontology, 73, 964 972.

Joachimski, M.M., van Geldern, R., Breisig, S., Buggisch, W. and Day, J. 2004. Oxygen isotope evolution of biogenic calcite and apatite during the Middle and Late Devonian. International Journal of Earth Sciences, 93, 542-553.

Jones, R.K. and Turner, S. 2000. Late Devonian fauna from the Columbine Sandstone (Coffee Hill Member), Gap Creek, central New South Wales. In: Blieck, A. and Turner, S. (Eds), Palaeozoic Vertebrate Biochronology and Global Marine/Non-marine Correlation (final report IGCP 328, 1991-1996). Courier Forschungsinstitut Senckenberg, 223, 523-542.

Kaufmann, B. 1998. Facies, stratigraphy and diagenesis of Middle Devonian reef and mud mounds in the Mader (eastern Anti-Atlas, Morocco). Acta Geologica Polonica, 48, 43-106.

Kiaer, J. 1932. New coelolepids from the Upper Silurian on Oesel (Esthonia). Eesti Loodusteaduse Arhiiv, Seeria 1, 10, 167-176.

Klapper, G. 1989. The Montagne Noire Frasnian (Upper Devonian) conodont succession. In: McMillan, N.J, Embry, A. F. and Glass, D.J. (Eds), Devonian of the World, Canadian Society of Petroleum Geologists Memoir, 14, 449468.

Klapper, G. 1995. Preliminary analysis of Frasnian, Late evonian conodont biogeography. Historical Biology, 10, 103-117.

Klapper, G. 2007. Frasnian (Upper Devonian) conodont succession at Horse Spring and correlative sections, Canning Basin, Western Australia. Journal of Paleontology, 81, 513-537.

Lund, R. 1974. Stethacanthus altonensis (Elasmobranchii) from the Bear Gulch Limestone of Montana. Annals of the Carnegie Museum, 45, 161-178.

Lelièvre, H. and Derycke, C. 1998. Microremains of verte- brates near the Devonian-Carboniferous boundary of Southern China (Hunan province) and their biostratigraphical significance. Revue de Micropaléontologie, 41, 297-320.

Li, G.Q. 1988. A new species of Protacrodus from northern Jiangsu. Vertebrata Palasiatica, 26, 101-106.

Liao, J.C., Ginter, M. and Valenzuela-Rios, J.I. 2007. Chondrichthyan microremains from the Givetian of the Aragonian Pyrenees (Spain). Bulletin de la Société Géologique de France, 178, 171-178.

Liszkowski, J. and Racki, G. 1993. Ichthyoliths and deepening events in the Devonian carbonate platform of the Holy Cross Mountains. Acta Palaeontologica Polonica, 37, 407-426.

Long, J.A. 1987. A new dinichthyid fish (Placodermi; Arthrodira) from the Upper Devonian of Western Australia, with a discussion of dinichthyid interrelationships. Records of the Western Australian Museum, 13, 515-540.

Long, J.A. 1991. Devonian fish remains from the Munabia Sandstone, Carnarvon Basin, Western Australia. Records of the Western Australian Museum, 15, 503-515.

Long, J.A. (Ed.) 1993. Palaeozoic Vertebrate Biostratigraphy and Biogeography. Belhaven Press; London.

Long, J. 2006. Swimming in Stone - the Amazing Gogo Fossils of the Kimberley. Fremantle Arts Centre Press; Fremantle.

Long, J.A. and Burrett, C.F. 1989. Fish from the Upper Devonian of the Shan-Thai Terrane indicate proximity to East Gondwana and South China Terranes. Geology, 17, 811-813.

Long, J.A. and Hairapetian, V. 2000. Famennian microvertebrates from the Dalmeh area, central Iran. Records of the Western Australian Museum, Supplement, 58, 211-221.

Long, J.A. and Trinajstic, K. 2000. An overview of the Devonian microvertebrate faunas of Western Australia, 471486. In: Blieck, A. and Turner, S. (Eds), Palaeozoic vertebrate biochronology and global marine/non-marine correlation - Final report of the IGCP 328 (1991-1996). Courier Forshungsinstitut Senckenberg, 223, 1-575.

Long, J.A. and Trinajstic, K. 2010. The Late Devonian Gogo Formation Lagerstatte of Western Australia: Exceptional Early Vertebrate Preservation and Diversity. Annual Review of Earth and Plantary Sciences, 38, 255-279.

Lund, R. 1974. Stethacanthus altonensis (Elasmobranchi) from the Bear Gulch Limestone of Montana. Annals of the Carnegie Museum, 45, 43-56.

Maisey, J.G. 2001. A primitive chondrichthyan braincase from the Middle Devonian of Bolivia. In: Ahlberg, P. (Ed.), Major events in Early Vertebrate Evolution, 263-288. Paleontology, Phylogeny and Development; London.

Märss, T., Fredholm, D., Talimaa, V., Turner, S., Jeppsson, L. and Nowlan, G. 1995. Silurian Vertebrate Biozonal Scheme. In: Lelievre, H., Wenz, S., Blieck, A. and 
Cloutier, R. (Eds), Premiers Vertèbrès et Vertèbrès Inferieurs. Geobios, 19, 368-372.

Märss, T., Turner, S. and Karatajūtė-Talimaa, V.N. 2007. Agnatha II: Thelodonti. In: Shultze H.P. (Ed.), Handbook of Paleoichthyology, Volume 1B, 1-143. Verlag Dr. Friedrich Pfeil; München.

McNamara, K.J. and Feist, R. 2006. New styginids from the Late Devonian of Western Australia - The last corynexochid trilobites. Journal of Paleontology, 80, 98192.

Metzger, R.A. 1994. Multielement reconstructions of Palmatolepis and Polygnathus (Upper Devonian, Famennian) from the Canning Basin, Australia and Bactrian Mountain, Nevada. Journal of Paleontology, 68, 617-647.

Metcalfe, I. 1984. Stratigraphy, palaeontology and palaeogeography of the Carboniferous of Southeast Asia. Memoires de La Société Géologiqu de France, 147, 107-118.

Metcalfe, I. 2001. Palaeozoic and Mesozoic tectonic evolution and biogeography of SE Asia-Australasia. In: Metcalfe, I., Smith, J.M.B., Morwood, M., Davidson, I. (Eds), Faunal and Floral Migrations and Evolution in SE Asia-Australasia. A.A, Balkema, Lisse.

Metcalfe, I. 2011. Palaeozoic-Mesozoic history of South Asia. In: Hall, R., Cottam, M. and Wilson, M.E.J. (Eds), The SE Asian Gateway: History and Tectonics of the Australia-Asia Collision. Geological Society, London, Special Publication, 355, 7-35.

Nance, R.D., Gutiérrez-Alonso, G., Keppie, J.D., Linnemann, U., Murphy, J.B., Quesada, C., Strachan, R.A. and Woodcock, N. 2012. A brief history of the Rheic Ocean. Geoscience Frontiers, 3, 125-135.

Newberry, J.S. 1889. The Paleozoic fishes of North America. U.S. Geological Survey, Monograph, 16, 1-340.

Nicoll, R.S. and Playford, P.E. 1993. Upper Devonian iridium anomalies, conodont zonation and the Frasnian-Famennian boundary in the Canning Basin, Western Australia. Palaeogeography, Palaeoclimatology, Palaeoecology, 104, 105-113

Obruchev, D.V. 1964. Agnatha and fish. In: Orlov, Y.U. (Ed.). Fundamentals of Palaeontology, 11, 1-522, Nauka; Moscow.

Owen, R. 1846. Lectures on the comparative anatomy and physiology of the vertebrate animals, delivered at the Royal College of Surgeons of England in 1844 and 1846. Part 1: Fishes, 1-308. Longman, Brown, Green, and Longmans; London.

Parmley, D. and D. J. Cicimurri. 2003. Late Eocene sharks of the Hardie Mine local fauna of Wilkinson County, Georgia. Georgia Journal of Science, 61, 153-179.

Peterson, M.S. 1975. Upper Devonian (Famennian) ammonoids from the Canning Basin, Western Australia. $\mathrm{Pa}$ leontological Society, 8, 1-55.

Pfeil, F.H. 1983. Zahnmorphologische Untersuchungen an rezenten und fossilen Haien der Ordnungen Chlamydoselachiformes und Echinorhiniformes. Palaeoichthyologica, 1, 1-315.

Peyer, B. 1968. Comparative Odontology. University of Chicago Press; Chicago.

Playford, P.E. 1980. Devonian 'Great Barrier Reef' of the Canning Basin, Western Australia. American Association of Petroleum Geologists, 6, 814-840.

Playford, P.E. and Lowry D.C. 1966. Devonian reef complexes of the Canning Basin, Western Australia. Geological Survey of Western Australia Bulletin, 118, 1-150.

Playford, P.E., Hocking, R.M. and Cockbain. A.E. 2009. Devonian reef complexes of the Canning Basin. Geological Survey of Western Australia Bulletin, 145, 1-444.

Playton, T. E., Montgomery, P., Tohver, E., Hillbun, K., Katz, D., Haines, P., Trinajstic, K., Yan, M., Hansma, J., Pisarevsky, S., Kirschvink, J., Cawood, P., Grice, K., Tulipani, S., Ratcliffe, K., Wray, D., Caulfield-Kerney, S., Ward, P. and Playford, P.E. 2013. Development of a regional stratigraphic framework for Upper Devonian reef complexes using integrated chronostratigraphy: Lennard Shelf, Canning Basin, Western Australia. In: Keep, M. and Moss, S.J. (Eds), The Sedimentary Basins of Western Australia IV. Proceedings of the Petroleum Exploration Society of Australia Symposium, Perth, Western Australia.

Raschi, W., Musick, J.A. and Compagno, L.J.V. 1982. Hypoprion bigelowi, a synonym of Carcharhinus signatus (Pisces: Carcharhinidae), with a description of ontogenetic heterodonty in this species and notes on its natural history. Copeia, 1982, 102-109.

Rode, A.L. and Lieberman, B.S. 2005. Integrating evolution and biogeography: A case study involving Devonian crustaceans. Journal of Paleontology, 79, 267-276.

Sandberg, C.A., Morrow, J.R. and Warme, J.E. 1997. Late Devonian Alamo impact event, global Kellwasser events, and major eustatic events, eastern Great Basin, Nevada and Utah. Brigham Young University, Geology Studies, 42, 129-160.

Scotese, C.R. and McKerrow, W.S. 1990. Revised World maps and introduction. In: McKerrow, W.S. and Scotese, C.R. (Eds), Palaeozoic Palaeogeography and Biogeography. Geological Society, London, Memoir, 12, 1-21.

Seddon, G. 1969. Conodont and fish remains from the Gneudna Formation, Carnarvon Basin, Western Australia. Journal of the Royal Society of Western Australia, 52, 2130.

Southgate, P.N., Kennard. J.M., Jackson, M.J., O’Brien, P.E. and Sexton, M.J. 1993. Reciprocal lowstand clastic and highstand carbonate sedimentation, subsurface Devonian reef complex, Canning Basin, Western Australia. In: Loucks, R.G. and Sarg, J.F. (Eds), Carbonate sequence stratigraphy, recent developments and applications. Amer- 
ican Association of Petroleum Geologists, Memoir, 57, 157-159.

St. John, O. and Worthen, A.H. 1875. Part II. Palaeontology of Illinois, Section I: Description of Fossil Fishes. Geological Survey of Illinois, 6, 247-488.

Straube, N., Schliewen, U. and Kriwet, J. 2008. Dental structure of the Giant lantern shark Etmopterus baxteri (Chondrichthyes: Squaliformes) and its taxonomic implications. Environmental Biology of Fishes, 82, 133-141.

Stephens, N.P and Sumner, D.Y. 2003. Famennian microbial reef facies, Napier and Oscar Ranges, Canning Basin, Western Australia. Sedimentology, 50, 1283-1302.

Talimaa, V. 2000. Significance of thelodonts (Agnatha) in correlation of UpperOrdovician to Lower Devonian of the northern part of Eurasia. In: Blieck, A. and Turner, S. (Eds), Palaeozoic Vertebrate Biochronology and Global Marine/Non-marine Correlation (final report IGCP 328, 1991-1996). Courier Forschungsinstitut Senckenberg, 223, 69-80.

Trinajstic, K. and George, A.D. 2009. Microvertebrate biostratigraphy of Upper Devonian (Frasnian) carbonate rocks in Canning and Carnarvon Basins of Western Australia. Palaeontology, 52, 641-659.

Trinajstic, K. 1999a. New anatomical information on Holonema (Placodermi) based on material from the Frasnian Gogo Formation and the Givetian-Frasnian Gneudna Formation, Western Australia. Geodiversitas, 21, 69-84.

Trinajstic, K. 1999b. Scale morphology of the Late Devonian palaeoniscoid Moythomasia durgaringa Gardiner and Bartram, 1977. Alcheringa, 23, 9-19.

Trinajstic, K. 2001. A description of additional variation seen in the scale morphology of the Frasnian thelodont Australolepis seddoni Turner and Dring, 1981. Records of the Western Australian Museum, 20, 237-246.

Trinajstic, K., Roelofs, B., Burrow, C.J., Long, J.A. and Turner, S. 2014. Devonian vertebrates from the Canning and Carnarvon Basins with an overview of Paleozoic vertebrates of Western Australia. Journal of the Royal Society of Western Australia, 97, 133-151.

Turner, S. 1973. Siluro-Devonian thelodonts from the Welsh Borderland. Journal of the Geological Society of London, 129, 557-584.

Turner, S. 1982. Middle Palaeozoic elasmobranch remains from Australia. Journal of Vertebrate Paleontology, 2, 117-131.

Turner, S. 1993. Palaeozoic microvertebrates from eastern Gondwana. In: Long, J.A. (Ed.), Palaeozoic Vertebrate Biostratigraphy and Biogeography, 174-207. Belhaven Press; London.

Turner, S. 1995. Devonian thelodont scales (Agnatha, Thelodonti) from Queensland. Memoirs of the Queensland Museum, 38, 677-685.

Turner, S. 1997. Sequence of Devonian thelodont scale as- semblages in East Gondwana. In: Paleozoic Sequence Stratigraphy, Biostratigraphy, and Biogeography: Studies in Honor of Dr J. Granville ("Jess") Johnson: Boulder, Colorado, Klapper, G, Murphy, M.A. and Talent, J.A. (Eds). Geological Society of America, Special Paper, 321, 295-315.

Turner, S. 1999. Early Silurian to Early Devonian thelodont assemblages and their possible ecological significance. In: Boucot, A.J. and Lawson, J. (Eds), Palaeocommunities: a case study from the Silurian and Lower Devonian. International Geological Correlation Programme 53, Project Ecostratigraphy, Final Report, 42-78. Cambridge University Press; Cambridge.

Turner, S. and Dring, R.S. 1981. Late Devonian thelodonts (Agnatha) from the Gneudna Formation, Carnarvon Basin, Western Australia. Alcheringa, 5, 39-48.

Turner, S and Youngquist, W. 1995. Late Devonian phoebodont (Chondrichthyes) from the Confusion Range, Utah, USA. Geobios Mémoire Spécial, 19, 389-392.

Turner, S., Burrow, C. J., Gholomalian, H. and Yazdi, M. 2002. Late Devonian (early Frasnian) microvertbrates and conodonts from the Chahriseh area near Esfahan, Iran. Association of Australasian Palaeontologists Memoir, 27, 149-159.

Valiukevičius, J. 1995. Acanthodians from marine and nonmarine Early and Middle Devonian deposits. In: Lelievre, H., Wenz, S., Blieck, A. and Cloutier, R. (Eds), Premiers Vertébrés et Vertébrés inférieurs (Ville Congress International, Paris, 4-9 Sept. 1995). Geobios, Mémoire Spécial, 19, 393-397.

Valiukevičius, J. and Krucheck, S. 2000. Acanthodian biostratigraphy and interregional correlations of the Devonian of the Baltic States, Belarus, Ukraine and Russia. In: Blieck, A. and Turner, S. (Eds), Palaeozoic Vertebrate Biochronology and Global Marine/Non-marine Correlation (Final Report of IGCP 328, 1991-1996). Courier Forschungsinstitut Senckenberg, 223, 271-289.

Wang, S.T. and Turner, S. 1995. A Reappraisal of Upper Devonian-Lower Carboniferous vertebrate microfossils in South China. Professional Papers of Stratigraphy and Palaeontology, 26, 59-70.

Wells, J.W. 1944. Fish remains from the Middle Devonian bone beds of the Cincinnati Arch Region. Palaeontographica Americana, 3, 5-62.

Williams, M.E. 1985. The "Cladodont level" sharks of the Pennsylvanian black shales of central North America. Palaeontolographica Abteilung A, 190, 83-158.

Yazdi, M. and Turner, S. 2000. Late Devonian and Carboniferous vertebrates from the Shishtu and Sardar Formations of the central Shotori Range, Iran. Records of the Western Australian Museum Supplement, 58, 223240.

Young, G.C. 1987. Devonian fish remains from Billiluna, 
eastern Canning Basin, Western Australia. BMR Journal of Australian Geology and Geophysics, 10, 179-192.

Young, G.C. 1995. Devonian. Australian Phanerozoic Timescales. Biostratigraphic charts and explanatory notes. Second Series. AGSO Record 1995/33, 1-47.

Young, G.C. and Turner, S. 2000. Devonian microvertebrates and marine-nonmarine correlation in East Gondwana: overview. In: Blieck, A. and Turner, S. (Eds), Palaeozoic Vertebrate Biochronology and Global Marine/Non-marine Correlation (final report IGCP 328, 1991-1996). Courier Forschungsinstitut Senckenberg, 223, 453-470.

Young. G.C. 2003. North Gondwana mid-Palaeozoic con- nections with Euramerica and Asia: Devonian vertebrate evidence. Courier Forschungsinstitut Senckenberg, 242, 169-185.

Young, G.C., Burrow, C.J., Long, J.A., Turner, S. and Choo, B. 2010. Devonian macrovertebrate assemblages and biogeography of East Gondwana (Australasia, Antarctica). Palaeoworld, 19, 55-74.

Zangerl, R. 1981. Paleozoic Elasmobranchii. In: Schultze, H.P. (Ed.), Handbook of Paleoichthyology 3A, 1-115. Gustav-Fischer; Stuttgart, New York.

Ziegler, W. and Sandberg, C.A. 1990. The Late Devonian standard conodont zonation. Courier Forshungsinstitut Senckenberg, 121, 1-115.

Manuscript submitted: $10^{\text {th }}$ October 2014

Revised version accepted: $15^{\text {th }}$ December 2014 
UPPER DEVONIAN MICROVERTEBRATES FROM WESTERN AUSTRALIA 